\title{
New interpretation of the basal Bambuí Group, Sete Lagoas High (Minas Gerais, E Brazil) by sedimentological studies and regional implications for the aftermath of the Marinoan glaciation: Correlations across Brazil and Central Africa
}

\author{
Franck R.A DELPOMDOR ${ }^{1,2,3, *}$, Archange M. ILAMBWETSI ${ }^{1,2}$, FABricío A. CAXITO ${ }^{1,2}$ \& Antonio C. PEDROSA-SOARES ${ }^{1,2}$
}

${ }^{1}$ Universidade Federal de Minas Gerais, CPMTC-IGC-UFMG, Campus Pampulha, Belo Horizonte, Minas Gerais 31270-901, Brazil. E-mails:delpomdor.franck@gmail.com; i.archange2@gmail.com; caxito@ufmg.br; pedrosasoares@gmail.com.

${ }^{2} \mathrm{CNPq}$ - Brazilian Scientific and Technological Research Council, Science Without Borders Program.

${ }^{3}$ Illinois State Geological Survey, University of Illinois at Urbana-Champaign, Champaign, US61820, USA.

* corresponding author: delpomdorfranck@gmail.com.

\begin{abstract}
Along the preserved southeast border (i.e., the Sete Lagoas High) of the Bambuí basin, the Pedro Leopoldo Member, basal succession of the Sete Lagoas Formation, unconformably overlies the Archean basement, and mostly includes carbonates with thin pelite intercalations and rare ruditic deposits. One of these, the so-called Carrancas conglomerate in its type-section, has been considered one of the lowermost rudite deposits of the Bambuí basin, being frequently ascribed to a Neoproterozoic glaciation. However, our detailed study, based on facies analysis, reveals that the Carrancas conglomerate was deposited by sediment gravity flow currents within the basal Pedro Leopoldo Member. Two outcrop sections in the São José de Lapa and Vespasiano areas, including thirteen abandoned quarry-cut and cliff outcrops, display eight distinct lithofacies (LF1 to LF8) forming a shallowing-upward carbonate ramp succession. It is composed, from the base to the top, by a mixed siliciclastic-carbonate outer ramp distally bounded by a slope-outer ramp system with sediment gravity flow deposits, a deep outer ramp developed below storm-wave base environments, an outer-middle ramp with aragonite pseudomorph crystal fans developed in $\mathrm{CaCO}_{3}$ oversaturated below storm-wave base environment in suboxic/anoxic conditions. According to published isotope data correlating $\delta^{13} \mathrm{C}$ trends and values in basal carbonates of the Pedro Leopoldo Member of the Sete Lagoas and Januária highs, the relatively deep outer-slope ramp mixed siliciclastic-carbonate units of the study area appear to be coeval in age with the cap dolostone of shallow-water inner ramp of the Januária High. The absence of a cap dolostone in the Sete Lagoas High could be explained by lack of accommodation space or a regional erosion due to the tectonically driven forebulge uplift of the Sete Lagoas High. The Pedro Leopoldo Member in the Sete Lagoas High was accumulated in a brine-seawater bottom waters under suboxic/anoxic conditions in the relatively deeper portion of the carbonate ramp system, whilst the cap dolostone in the Januária High was developed in oxygenated mixed layer and intermediate water near the surface water in the shallower portion of the carbonate ramp system. Such lateral variations of facies and $\delta^{13} \mathrm{C}$ fluctuations are similar to those recorded by the cap carbonate sequences of the basal Schisto-Calcaire/Lukala (Sub)Group in the West Congo Belt and the basal Araras Group in the Paraguay Belt, which display a similar wide range of sub-environments like the studied part of the Pedro Leopoldo Member.
\end{abstract}

KEYWORDS: Carrancas conglomerate, sediment gravity flow, Sete Lagoas Formation, Bambuí Group, Brazil.

\section{Introduction}

For several decades, outcrops showing rudite deposits at the base of the lowermost carbonate-pelite unit of the Bambuí Group, like those located at km-30 marker of the MG-424 roadway near São José de Lapa (Minas Gerais, eastern Brazil), firstly described by Costa \& Branco (1961) as the type-section of the rudite-bearing Carrancas Formation, have been associated with Neoproterozoic glacial events (Martins-Neto et al., 2001; Sgarbi et al., 2001; Romano \& Knauer, 2003; Uhlein et al., 2004, 2012, 2016; Romano, 2007; Ribeiro et al., 2008; Kuchenbecker et al., 2013, 2016; Babinski et al., 2012; Uhlein, 2014; Reis \& Alkmim, 2015). More recently, this unit has been the subject of facies and stratigraphy analysis from type-sections in the Sete Lagoas High, southern Bambuí basin, which have been newly interpreted as showing no evidence of glacial Cryogenian activity (Vieira et al., 2007; Rodrigues, 2008; Tuller et al., 2010). Caxito et al. (2012) interpreted the conglomeratic unit at these outcrops, as derived from local reworking of the basal platform of the lowermost unit of the Sete Lagoas Formation, along with its underlying basement. Other outcrops in adjacent areas commonly ascribed to the Carrancas Formation were recently re-interpreted as preglacial units deposited along fault margins (Uhlein et al., 2012, 2016). Recent chemostratigraphic studies on this stratigraphic interval supported general correlation with the lowermost part of the Sete Lagoas Formation (Santos et al., 2000; Kuchenbecker, 2011; Caxito et al., 2012; Guacaneme et al., 2017; Paula-Santos et al., 2017) as similar to those described in Neoproterozoic postglacial Marinoan successions worldwide (Hoffman \& Schrag, 2002; Halverson et al., 2005).

In this paper, we present a new detailed facies analysis of the Pedro Leopoldo Member, basal Bambuí Group, carried out along two key sections, one of them close to São José da Lapa, the previously considered type-section of the Carrancas Formation located at km-30 marker of the MG-424 roadway, and the other in the surroundings of Vespasiano, in order to clarify the depositional environments and the sedimentological processes of a sedimentary succession up to $30 \mathrm{~m}$ thick. Our study reveals that the rudite facies, previously interpreted as belonging to the Carrancas Formation, is actually a $40 \mathrm{~cm}$-thick intraformational conglomerate lens between sandy carbonate layers, bound above and below by abrupt contacts. Thus, the whole section is here re-interpreted and considered as part of the Pedro Leopoldo Member. The Pedro Leopoldo Member in the Sete Lagoas High is compared with a typical cap carbonate facies in the Januária High, northern portion of the Bambuí basin. Interbasinal correlations between the basal Bambuí Group and the Schisto-Calcaire/ Lukala (Sub)Group of the West Congo Belt in Central Africa and the Araras Group of the Paraguay Belt in central-western Brazil, are also discussed to evaluate possible chrono-correlations. We also examine their broader depositional setting that probably has occurred after the Marinoan glaciation, which in turn should provide constraints for models on the glaciation event.

\section{Geological setting}

The Bambuí basin covers more than $300,000 \mathrm{~km}^{2}$ of the São Francisco Craton in eastern Brazil (Dardenne, 1978; Sial et al., 2009). The eastern and western borders of the Bambuí basin comprise the Brasiliano Araçuaí and Brasília orogenic belts, respectively (Fig. 1A; Trompette, 1994; Cordani et al., 2000; Martins-Neto et al., 2001). The basin is divided into the Sete Lagoas Basement High to the south, which is separated from the Januária Basement High to the north by the WNW-trending Pirapora Aulacogen (Fig. 1A; Reis et al., 2016). The entire basin is covered by a 450 to $1800 \mathrm{~m}$-thick Neoproterozoic to Cambrian sedimentary succession of the Bambuí Group, unconformably overlying the Archean-Paleoproterozoic basement. According to Dardenne (1978), the Bambuí basin includes seven stratigraphic units, from the base to the top: (1) the Jequitai Formation, composed of glaciogenic diamictite, conglomerate, sandstone and pelite; (2) the Carrancas Formation, considered younger than the Jequitaí Formation (stratigraphic position updated by Caetano-Filho et al., 2019), mainly comprising rudite, sandstone, pelite and locally limestone at the top (Uhlein et al., 2012, 2016); 


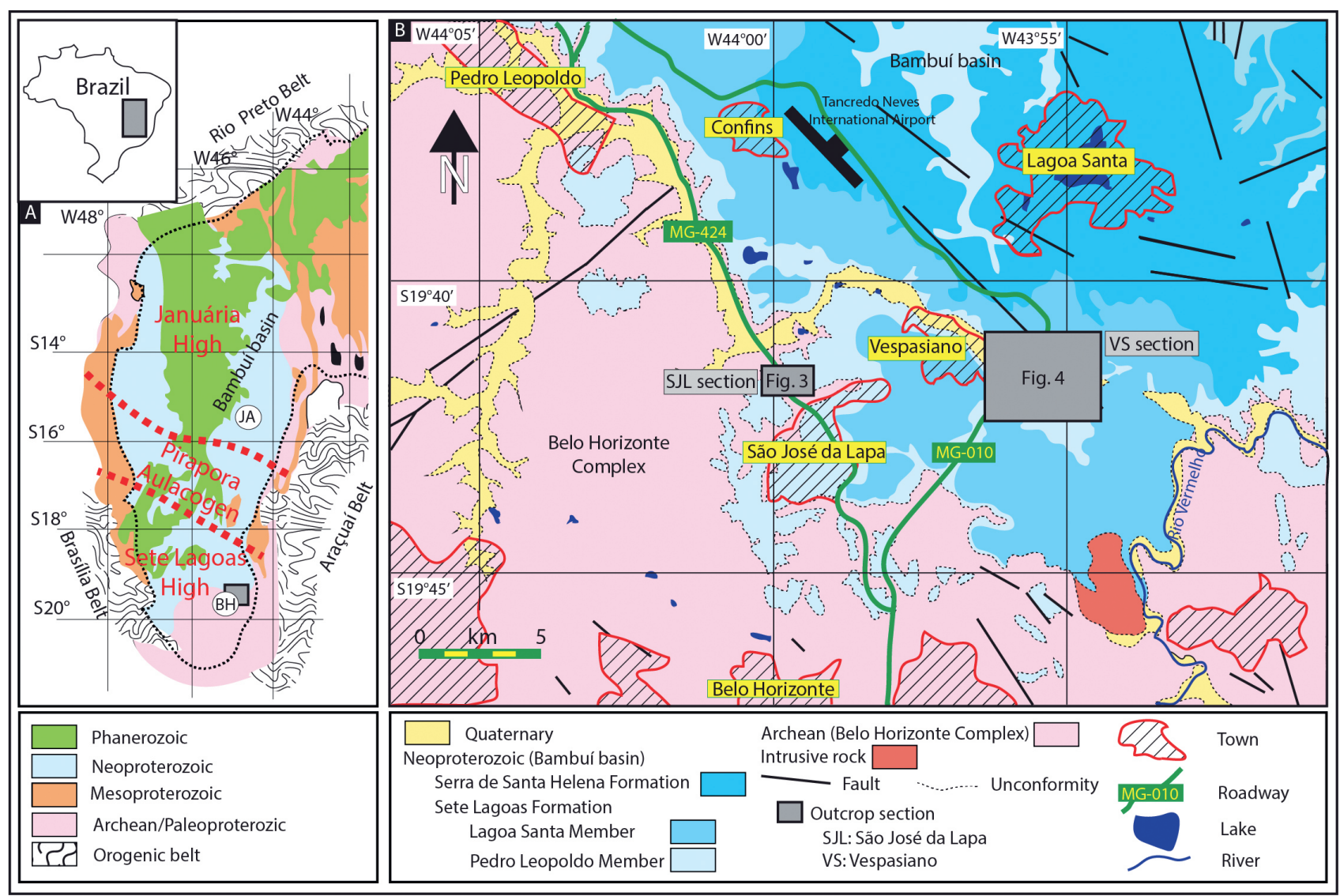

Figure 1. (A) Simplified geological map of the Bambuí basin in the São Francisco Craton (modified from Alkmim et al., 2006) including the Sete Lagoas Basement High to the south that is separated from the Januária Basement High to the north by the Pirapora Aulacogen (data based on Bouguer map published in Reis, 2011). (B) Sketched geological map of north Belo Horizonte including the regional geological repartition of the lowermost part of the Bambuí Group, including Sete Lagoas and Serra de Santa Helena formations (modified after Tuller et al., 2010). Location of outcrop sections at São José da Lapa and Vespasiano. Abbreviations: BH, Belo Horizonte; JA, Januária; SJL, São José da Lapa; VS, Vespasiano.

(3) the Sete Lagoas Formation mainly consisting of limestone and dolomite, subdivided into the Pedro Leopoldo and Lagoa Santa members (Ribeiro et al., 1991); (4) the Serra de Santa Helena Formation composed of siltstone, pelite and rhythmite; (5) the Lagoa do Jacaré Formation mainly comprising oolitic limestone and siltstone; (6) the Serra de Saudade Formation mainly composed of sandstone, siltstone and pelite; and (7) the Três Marias Formation mainly consisting of sandstone, conglomerate and pelite (Fig. 2). Located in the western portion of the basin, the Samburá Formation, mainly composed of conglomerate, and the Lagoa Formosa Formation, comprising diamictite, sandstone, siltstone with lenses of limestone and jaspilite, have been considered as lateral stratigraphic equivalents of the lower Sete Lagoas Formation (i.e., the Pedro Leopoldo Member) and of the Serra de Saudade Formation, respectively (Uhlein et al., 2011, 2017). The Jaíba Formation or Member, mainly composed of limestone, is interleaved between the Serra de Saudade and Três Marias formations in the north-eastern portion of the basin (Chiavegatto et al., 2003; Caxito et al., 2016) (Fig. 2).

\section{Geochronology}

The depositional age of the Bambuí Group, especially its lower part, remains controversial (Fig. 2). A Pb-Pb whole-rock isochron array of $740 \pm 22 \mathrm{Ma}$ on the lowermost part of the Sete Lagoas carbonates at the Sambra quarry, near Sete Lagoas town, has indicated a probably post-Sturtian age (Babinski et al., 2007), in agreement with the maximum depositional age ( $\sim 880 \mathrm{Ma})$ for the Jequitaí diamictites that were related to the Sturtian glaciation (Vieira et al., 2007; Rodrigues, 2008; Babinski et al., 2012). However, Caxito et al. (2012) and Alvarenga et al. (2014) proposed a post-Marinoan age $(\geq 635 \mathrm{Ma})$ for the lowermost part of the Sete Lagoas Formation, according to lithostratigraphic features (presence of less than $2 \mathrm{~m}$-thick pink dolostone, interpreted as "cap carbonate", at the base of the unit, throughout the basin; see Caxito et al., 2012, 2018), upwards-decreasing carbon isotope profiles, and ${ }^{87} \mathrm{Sr} /{ }^{86} \mathrm{Sr}$ signatures $(\sim 0.7074$ to 0.7080 ; see PaulaSantos et al., 2017). The lateral stratigraphic equivalent Samburá Formation yielded a maximum depositional age of $\sim 630 \mathrm{Ma}$ based on detrital zircon grains within conglomerate rocks (Uhlein et al., 2017). More recent geochronological results from the Sete Lagoas Formation imply a potentially younger Ediacaran age. Detrital zircons from the Sete Lagoas Formation are as young as $\sim 550 \mathrm{Ma}$ (Babinski et al., 2013), yielding a maximum age peak at $593 \pm 17 \mathrm{Ma}$ (Paula-Santos et al., 2015). This is supported by the occurrence of Cloudina sp. (i.e., considered as a coral-like cnidarian or a polychaete worm), a terminal Ediacaran index fossil $(\sim 550-541 \mathrm{Ma})$, recently found in the upper Sete Lagoas Formation in the Januária region, northern part of the basin (Warren et al., 2014). Crockford et al. (2018) recently provided a post-Marinoan (ca. $630 \mathrm{Ma}$ ) age for the cap carbonate rocks of the Sete Lagoas Formation in the Januária region, using triple oxygen and sulphur isotopes analysed on barite layers, which were coeval with the range of other negative triple oxygen isotope anomalies of post-Marinoan carbonates in Canada (see Crockford et al., 2016) and Norway (see Crockford et al., 2018). Those data, together with $\mathrm{K}-\mathrm{Ar}$ muscovite ages at $567 \pm 17 \mathrm{Ma}$ from garnetmica-schist and quartzite found in nappes of the external portion of the Brasília Orogen (Valeriano et al., 2004), thrusting upon sedimentary rocks of the basal Bambuí Group in the southwestern part of the basin, constrain the maximum age of the lower Sete Lagoas Formation between $630 \mathrm{Ma}$ and $560 \mathrm{Ma}$ (Uhlein et al., 2017).

\section{Materials and methods}

The study area approximately covers $30 \mathrm{~km}^{2}$ between São José da Lapa and Vespasiano that are located to the NNW Belo Horizonte, Minas Gerais, eastern Brazil (Fig. 1B). Two sections, that comprise abandoned quarry-cut and cliffs, were selected for sedimentary and sequence stratigraphy analyses. The São José da Lapa outcrop section, exposed at the km-30 marker of the MG- 


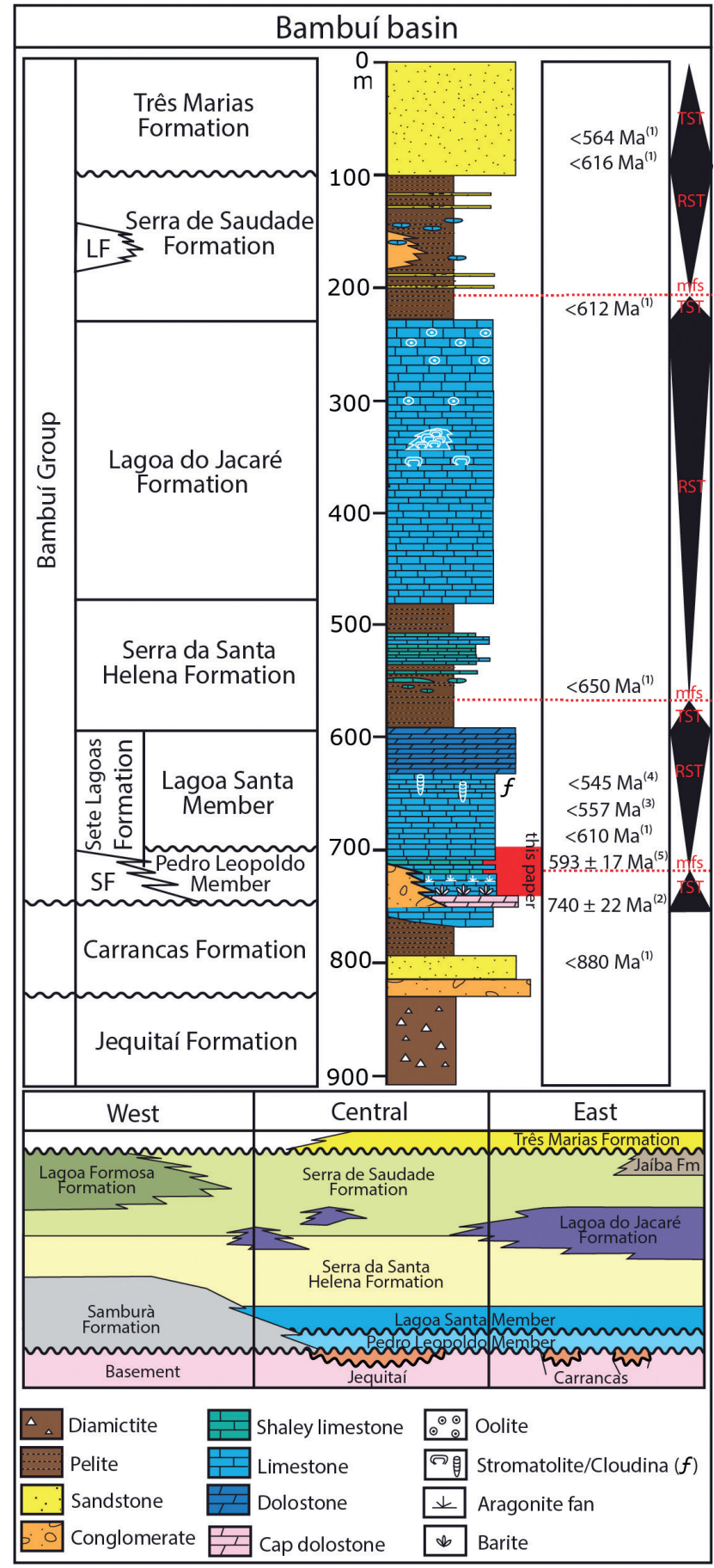

Figure 2. Composed lithostratigraphic subdivisions coupled with geochronology and sequence stratigraphy of the Bambuí Group (modified after Uhlein et al., 2017; Caetano-Filho et al., 2019). Geochronology: (1) Detrital zircon U-Pb age from Rodrigues (2008); (2) $\mathrm{Pb}-\mathrm{Pb}$ dating from Babinski et al. (2007); (3) Detrital zircon U-Pb age from Babinski et al. (2013); (4) Index fossil Cloudina sp. from Warren et al. (2014); (5) Detrital zircon U-Pb age from Paula-Santos et al. (2015). The box at below shows the west-east-trending basin distribution of stratigraphic units related to the foredeep (to the west)-forebulge (to the east) compartmentation (modified from Uhlein et al., 2017). Sequence stratigraphy is based on Martins \& Lemos (2007). Abbreviations: mfs, maximum flooding surface; RST, regressive system tract; TST, transgressive system tract.

424 roadway near São José da Lapa, occurs as six discontinuous cliff sections of the lower Pedro Leopoldo Member covered by soils and dense grass (Fig. 3A-B). In order to aid in outcrop description, trenches were dug around the main outcrops and revealed that the Carrancas diamictite-like rudite facies in the type-section is, in fact, interbedded with calcareous arenite facies (i.e., the classic Carrancas conglomerate does not lay beneath the lowest Sete Lagoas carbonates as previously considered in the literature since the early 1960's). The Vespasiano outcrop section, exposed along the MG-010 roadway near east Vespasiano, comprises five discontinuous cliff sections and one abandoned quarry-cut crossing the upper part of the Pedro Leopoldo Member (Fig. 4A). Eight lithofacies (LF1 to LF8) were distinguished according to their lithology, sedimentary structures, and bed geometry. To detail the geometry and internal structures of the beds, drawings from photographic sketches were prepared. The siliciclastic and carbonate classifications were based upon the size of the detrital grains published by Folk (1954). The terminology for carbonate rocks used "calcilutite" and "calcirudite" for carbonate rocks formed of mud- to silt-sized $(\leq 62.5 \mu \mathrm{m}$ in grain fraction) and granule- to cobble-sized ( $\geq 2 \mathrm{~mm}$ in grain fraction) clasts or bioclasts respectively.

The arrangement of clasts within the calcareous conglomerate (LF4, see above) was measured as a standard quantitative methodology (see Evans \& Benn, 2004) in the analysis of flow directions and the interpretation of depositional processes. The spatial arrangement of a clast is defined following three distinct orthogonal axis ( $\mathrm{a}, \mathrm{b}$ and $\mathrm{c}$ ), with the principal axis a, being parallel to the flow direction, and axis c normal to the preferred plane of the fabric (Evans \& Benn, 2004). One hundred thirtynine clasts, having a-axis longer than b-axis and with ratios greater than $1.5: 1$, in the approximate size range $8-50 \mathrm{~mm}$ were systematically selected in a small area covering less than $2 \mathrm{~m}^{2}$. The a-axis was measured following the azimuth and dip angle using a compass-clinometer. The data were presented in a rose diagram according to procedures in Evans \& Benn (2004). The a-axis measurements were restored to remove the effects of the regional deformation (bedding oriented 110/30NE) and allowing the original orientation of planes.

\section{Results}

The São José da Lapa outcrop section consists of an up 200 m-length N-S oriented incised valley, which is filled by up than $10 \mathrm{~m}$-thick weakly deformed sedimentary rocks uncomfortably covering migmatitic orthogneisses of the Archean Belo Horizonte Complex (Plate 1A). Trenches dug around the outcrop of the classic Carrancas conglomerate have revealed a lens-shaped intraformational rudite bed bound above and below, in abrupt contacts, by a calcareous arenite facies. This is solid evidence that the formerly so-called "classic Carrancas conglomerate" is, in fact, a rudite facies within the lower Pedro Leopoldo Member, the lowermost unit of the Sete Lagoas Formation, instead of being part of a separate formation, the Carrancas Formation as previously interpreted by Costa \& Branco (1961). The Archean Belo Horizonte Complex lies unconformably beneath the Bambuí Group that consists of less than $1 \mathrm{~m}$-thick weathered redcoloured diamictitic-like claystone attributed to the Carrancas Formation (Fig. 3C and Plate 1B). However, the contact between the Carrancas diamictite and the Pedro Leopoldo Member is not observed. Weathered diamictite and calcareous mudstone lithofacies are exposed in discontinuity on the south side of the MG-424 roadway, while the calcareous arenite, conglomerate, calcilutite, calcirudite, laminar and massive limestones lithofacies are located on the north side of the MG-424 roadway (Fig. 3C). The overall shape of outcrops is lenticular, E-W oriented, for the calcareous mudstone to calcirudite lithofacies, and tabular for laminar and massive limestones.

The Vespasiano outcrop section comprises an area of less than $1 \mathrm{~km}^{2}$ area of cliffs (VS1, VS2, VS3, VS5), isolated outcrops (VS4) and abandoned quarry-cut (VS6), which show 4 to 24 $\mathrm{m}$-thick exposures of weakly deformed sedimentary rocks of the upper part of the Pedro Leopoldo Member (Fig. 4A-C). From the base to the top, the outcrops consist of dark green-grey sericitic lime mudstone (Fig. 4B), locally interbedded by blue-grey crystalline massive limestone, passing to light to dark blue-grey fine- to medium-grained crystalline massive limestone, locally laminar, and blue-grey coarse-grained sandy limestone. The overall bedding is tabular, but a local lenticular bed is observed at the VS4 outcrop section.

The São José da Lapa and Vespasiano sections show that the lower and upper parts of the Pedro Leopoldo Member comprise eight distinct lithofacies that are described hereafter. 

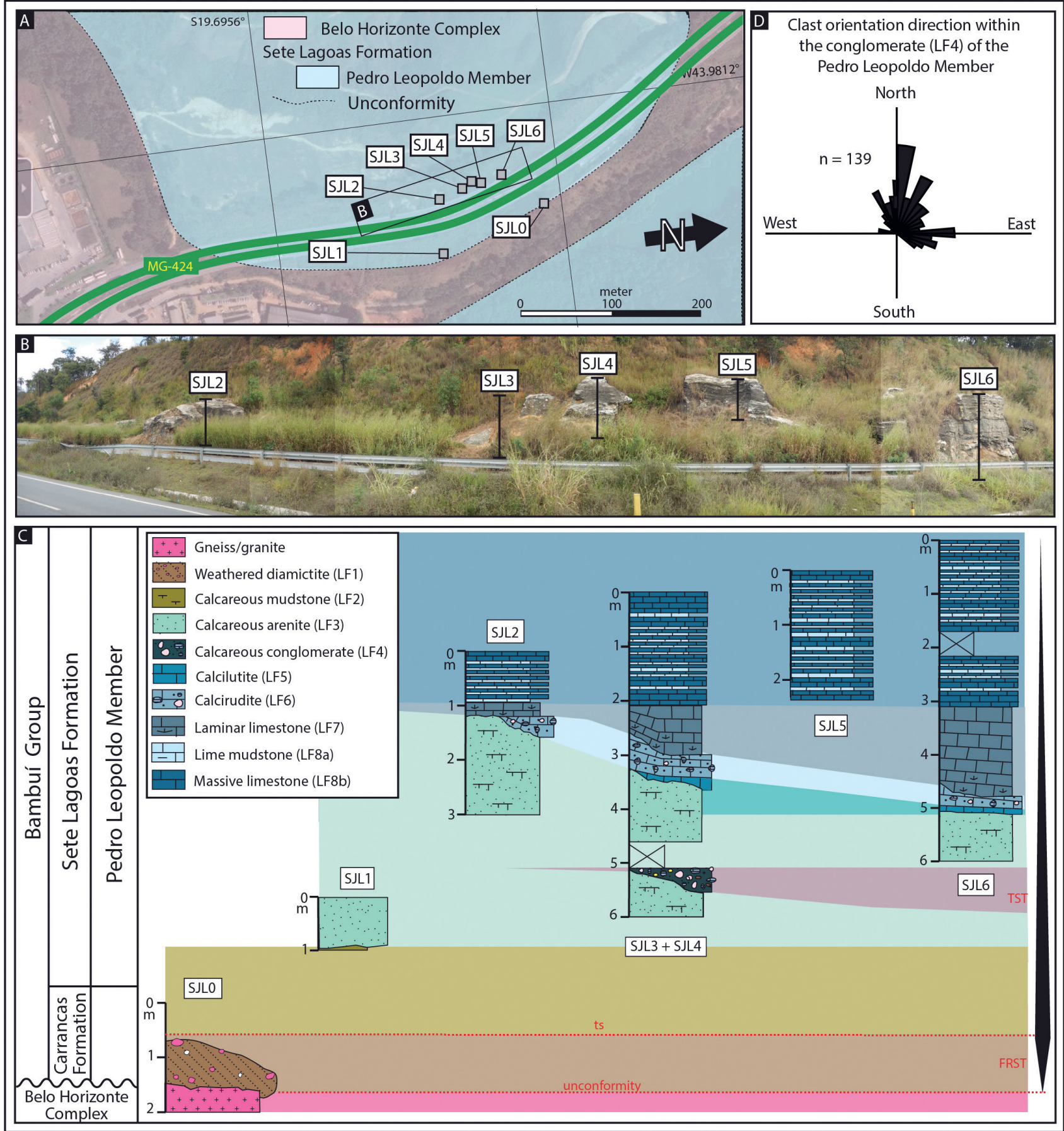

Figure 3. (A) Sketched geological map of the São José da Lapa section area at km-30 marker of the MG-424 roadway near São José da Lapa. Location of the studied outcrops (SJL are the location of outcrops) of the Carrancas Formation and the basal part of the Pedro Leopoldo Member; (B) Photograph of the N-S outcrop sections with location of outcrops; (C) Stratigraphic logs of the studied outcrops plotted in a N-S profile; (D) Polymodal orientation directions of the clasts within the conglomerate (LF4; see Section 5.1.). North- to northeast-dominated azimuths of flow direction from 139 measurements. Abbreviations: ts, transgressive surface; FRST, forced regressive system tract; TST, transgressive system tract.

\subsection{Lithofacies and facies associations}

Eight lithofacies (LF1 to LF8) are recognized in the Carrancas Formation and Pedro Leopoldo Member of the Sete Lagoas Formation. They are grouped into four lithofacies associations, LFA-1 to LFA-4, according to their lithology, sedimentary structures, textures, and are interpreted as deposited in several distinct environments. Lithofacies associations and lithofacies categories are summarized in Table 1.

\subsubsection{Lithofacies association 1 (LFA-1)}

LFA-1 includes the diamictite (LF1) and calcareous mudstone (LF2). LF1 consists of approximately $1 \mathrm{~m}$-thick weathered redto orange-coloured mud-supported polymictic diamictite with unsorted subangular-subrounded millimetre- to decimetre-sized clasts of crystalline rocks (gneiss and granite) and quartz (Plate
1B). The contacts with the Belo Horizonte Complex and LF2 are not observed. LF2 consists of successions of irregular alternations of light grey fine-grained calcareous mudstone beds (centimetreto decimetre-thick) and yellow-grey to green shale laminae (millimetre-thick) (Plate 1C). Rare small-scale continuous planar to wispy undulated parallel laminae and sand- to pebble-sized clasts of predominantly limestones are preserved. The overall shape of beds appears to be lenticular in small-scale outcrop. Its thickness in outcrop is approximately $20 \mathrm{~cm}$. The lower contact is not observed. The upper contact with the calcareous arenite (LF3) is erosional.

\subsubsection{Lithofacies association 2 (LFA-2)}

LFA-2 includes the calcareous arenite (LF3) and the calcareous conglomerate (LF4). LF3 consists of medium- to coarse-grained massive calcareous arenite (Plate 1C). The sand-sized grains 


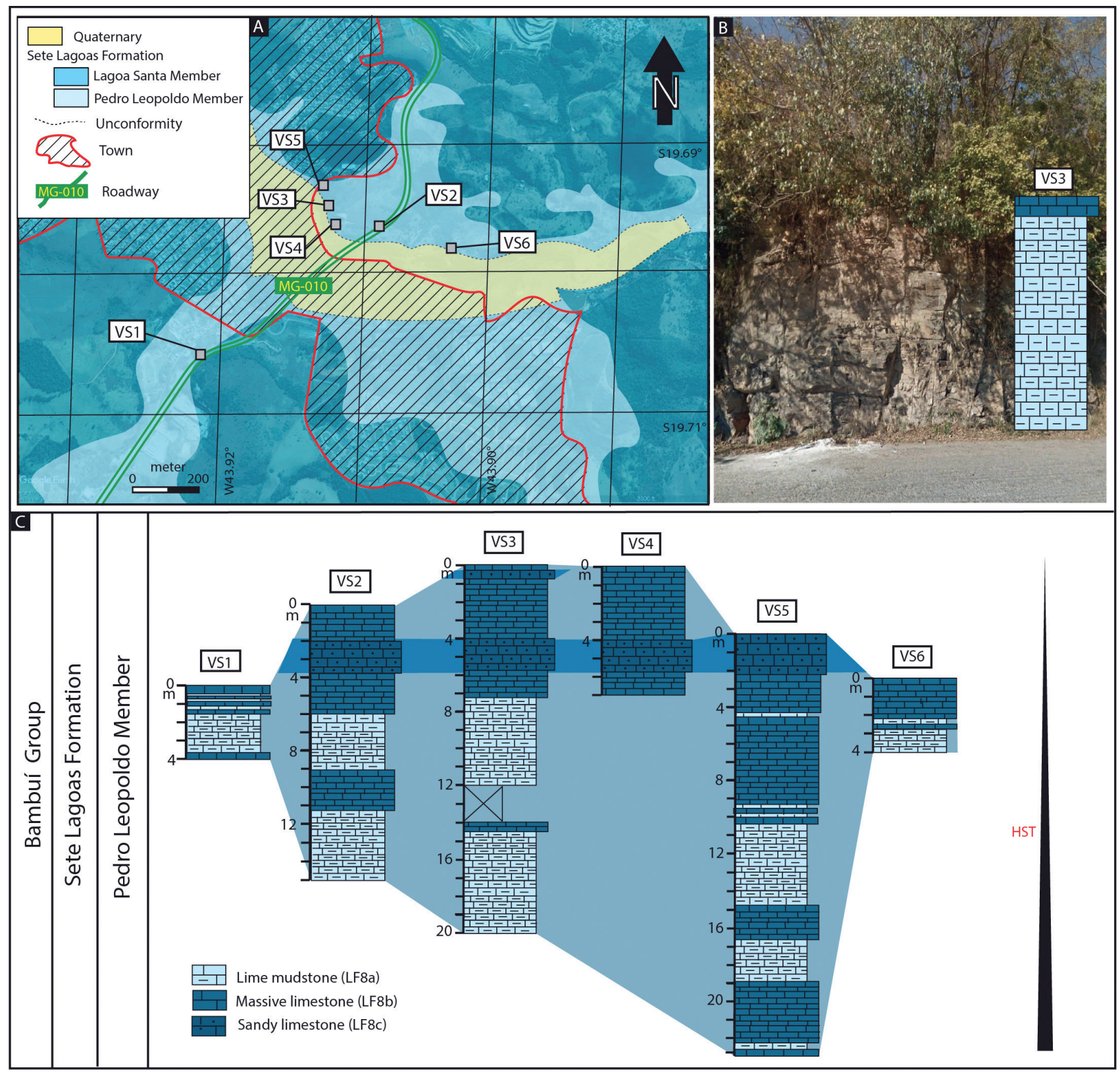

Figure 4. (A) Sketched geological map of the Vespasiano section area near Vespasiano. Location of the studied outcrops (VS are the location of outcrops) of the upper part of the Pedro Leopoldo Member; (B) Photograph of VS3 outcrops showing lime mudstone (LF8a) overlain by massive limestone (LF8b); (C) Stratigraphic logs of the studied outcrops at the Vespasiano section area. Abbreviations: HST, highstand system tract.

are predominantly angular and are composed of fragments of limestone and quartz in roughly equal proportions. Reverse gradation is locally observed. No sedimentary structures are observed. The shape of beds varies between lenticular and tabular. The basal contact is not observed. The upper contact is sharp. The lithofacies 4 (LF4) consists of one lenticular bed of conglomerate interbedded between calcareous arenite beds (LF3) (Plate 1D). Exposure is observed in $40 \mathrm{~cm}$-deep in a trench at São José da Lapa along the MG424 roadway (km 30). The lower contact is sharp, but flame-type structures and shears are apparently truncated by LF4 (Plate 1E). The upper contact is sharp or slightly undulating with the LF3. LF4 consists of a blue-grey grain-supported calcareous conglomerate with sand-to pebble-sized clasts of polymictic limestone, sandstone, quartz, granite and gneiss. Clasts of limestone predominate. The grains are subangular to subrounded (Plate 1D). The clasts show a preferential north to northeast orientation (Fig. 3D, see section 5.2.). Glacial features (e.g., striation on the surface of clasts) are absent.

\subsubsection{Lithofacies association 3 (LFA-3)}

LFA-3 consists of a dark grey poorly sorted massive calcilutite (LF5) and calcirudite (LF6). LF5 consists of blue-grey massive crystalline lime muddy matrix (Plate $1 \mathrm{~F}-\mathrm{G}$ ). No sedimentary structures are observed. The overall shape of beds is lenticular in outcrop. Its thickness is estimated around $1 \mathrm{~m}$. The basal contact is not visible. The upper contact is predominantly sharp or slightly undulating with local erosion (Plate 1F). LF6 consists of subangular to subrounded granule- to pebble-sized clasts of limestone partially supported by calcareous microstylolitic seams of muddy to silty matrix (Plate $1 \mathrm{~F}$ and $\mathrm{H}$ ). Rare clasts of gneiss are also observed. Several levels exhibit mud-supported autoclastic brecciated beds surrounded by light grey silty to sandy matrix (Plate $1 \mathrm{~J}-\mathrm{K}$ ). Autoclasts are dominantly composed of subangular to angular pebble-sized fragments of limestone. The thicknesses of these beds vary between 10 and $30 \mathrm{~cm}$. The thickness of overall beds varies between 1 and $2 \mathrm{~m}$. The basal contact is predominantly sharp or slightly undulating and is locally erosional. The upper contact is sharp. 
Table 1. Detailed lithofacies and lithofacies association description and environmental interpretation of the Carrancas Formation and the Pedro Leopoldo Member, basal Sete Lagoas Formation, at the São José da Lapa and Vespasiano section areas, north Belo Horizonte.

\begin{tabular}{cccc}
\hline $\begin{array}{c}\text { Lithofacies } \\
\text { associations }\end{array}$ & Lithofacies & General descriptions & $\begin{array}{c}\text { Depositional } \\
\text { environment }\end{array}$ \\
\hline
\end{tabular}

LF1

$1 \mathrm{~m}$-thick weathered red- to orange-coloured mud-supported polymictic diamictite with floating clasts. Clasts are unsorted subangular-subrounded millimetre- to decimetre in size including gneiss, granite and quartz. contacts Gravity flows with the Belo Horizonte Complex and LF2 are not observed.

LFA-1

Irregular alternations of centimetre- to decimetre-thick beds of light-grey fine-
LF2 grained calcareous mudstone beds and millimetre-thick horizons of yellow-grey

Below storm to green shales; upper contact with LF3 is erosional.

wave base outer

mixed siliciclasticcarbonate ramp

L3 Lenticular to tabular beds of medium- to coarse-grained massive calcareous arenite; reverse grading; upper contact is sharp.

LFA-2 Up than $40 \mathrm{~cm}$-thick lenticular interbed within LF3; blue-grey grain-supported

LF4 calcareous conglomerate with sand-to pebble-sized clasts of polymictic limestone, sandstone, granite and gneiss; prefrential north- to-northeast azimuth orientation directions of clasts; lower and upper contacts are sharp and erosive.

\begin{tabular}{|c|c|c|c|}
\hline \multirow[b]{2}{*}{ LFA-3 } & LF5 & $\begin{array}{l}1 \mathrm{~m} \text {-thick lenticular beds of blue-grey massive crystalline calcilutite; upper } \\
\text { contact is predominantly sharp or slightly undulating with local erosion. }\end{array}$ & $\begin{array}{l}\text { Below storm } \\
\text { wave base outer } \\
\text { carbonate ramp }\end{array}$ \\
\hline & LF6 & $\begin{array}{l}\text { 1-2 m-thick beds of calcirudite with granule- to pebble-sized clasts; calcareous } \\
\text { microstylolithic seams of muddy to silty matrix; autoclastic breccia; basal } \\
\text { contact is predominantly sharp or slightly undulating, and is locally erosional; } \\
\text { lower and upper contact are sharp. }\end{array}$ & $\begin{array}{l}\text { Slump in an outer } \\
\text { carbonate ramp }\end{array}$ \\
\hline \multirow[t]{2}{*}{ LFA-4 } & LF7 & $\begin{array}{l}\text { Centimetre-thick successions of irregular alternations of light grey crystalline } \\
\text { limestone and darker crystalline limestone with pseudomorphs of aragonite } \\
\text { crystal fans; lenticular to tabular beds; lower contact marked by low-relief } \\
\text { erosional surfaces; upper contact sharp. }\end{array}$ & \multirow{2}{*}{$\begin{array}{l}\text { Below to above } \\
\text { storm wave base } \\
\text { outer-midle } \\
\text { carbonate ramp }\end{array}$} \\
\hline & LF8 & $\begin{array}{l}\text { Centimetre- to decimetre-thick successions of alternations of light to dark blue- } \\
\text { grey coarse-grained crystalline massive limestone and dark green-grey lime } \\
\text { mudstone; lower contact is sharp. }\end{array}$ & \\
\hline
\end{tabular}

\subsubsection{Lithofacies association 4 (LFA-4)}

LFA-4 includes the laminar (LF7) and massive (LF8) limestones. The lithofacies 7 (LF7) consists of centimetre-thick successions of irregular alternations of light grey crystalline limestone and darker crystalline limestone with pseudomorphs of aragonite crystal fans arranged in growth position (Plate 1I and J). Aragonite crystal fans, ranging from $5 \mathrm{~mm}$ to $3 \mathrm{~cm}$ in size, are dark grey, elongate, and outwardly and upwardly radiating fans laterally connected to the light grey crystalline limestone layer (Plate 1L). Contacts between laminae are irregular and undulating. The aragonite crystals laminae are located in the lowermost part of the beds (approximately $30-50 \mathrm{~cm}$ ). Prismatic pyrites are locally visible. The overall shape of beds appears to be lenticular in outcrop (Plate 1I). However, the upper part of the beds is tabular. The thickness of overall beds varies from $30 \mathrm{~cm}$ to 1.5 $\mathrm{m}$. Basal contact is predominantly sharp and/or marked by lowrelief erosional surfaces (Plate 1J). The upper contact is sharp or slightly undulating with the massive limestone beds (LF8) (Plate 1I-J). LF8 consists of centimetre- to decimetre-thick successions of alternations of dark green-grey sericitic lime mudstone (LF8a) and light to dark blue-grey fine- to medium-grained crystalline massive limestone (LF8b) (Plate 1M). Atop the Pedro Leopoldo Member, blue-grey coarse-grained well-sorted sandy limestone interbeds (LF8c) are observed within the massive limestone beds. The contact between the mud limestone and massive limestone is slightly undulating to wavy. The overall shape of beds appears to be lenticular in outcrop. Thickening-upward beds over approximately $1 \mathrm{~m}$ section are observed at the base. The basal contact is sharp and the upper contact is not observed.

\subsection{Clast orientation}

The arrangement of clasts is plotted on a rose diagram using the a-axis bearings of 139 clast orientations collected from the calcareous conglomerate lithofacies (LF4) at the base of the Pedro Leopoldo Member at the São José da Lapa section (Fig. $3 \mathrm{D})$. All data are shown in Table 2 . The rose petal is preferentially oriented to north-northeast in the range $0-45^{\circ}$ for $37.8 \%$ of the measured a-axis. Second major arrangements of clasts are oriented northeast-east in the range $45-90^{\circ}$ and north-northwest in the range $320-360^{\circ}$ that represent $25.0 \%$ and $20.0 \%$ of measured a-axis respectively. A minor arrangement of clasts is oriented east-southeast in the range $90-135^{\circ}$ for $17.1 \%$ of measured a-axis.

\subsection{Interpretation}

The described re-examination of the formerly classic type-section of the Carrancas Formation, at the km-30 marker of the MG-424 roadway, allows us to conclude that the section is exclusively composed of different facies of the Pedro Leopoldo Member, and does not show any evidence of glacial deposits as suggested in previous papers (see Martins-Neto et al., 2001; Sgarbi et al., 2001; Romano \& Knauer, 2003; Ribeiro et al., 2008; Reis \& Alkmim, 2015). Detailed field descriptions of lithofacies, reported in the present paper, lead us to re-interpret the depositional environments along the studied area. The succession of lithofacies records a shallowing-upward setting in distally steepened or slope ramp environments to below storm-influenced sediments in outer ramp environments.

Lithofacies association 1 (LFA-1) includes the diamictite (LF1) and calcareous mudstone lithofacies (LF2) that record 
Table 2. Measurements of orientation directions of clasts within the conglomerate (LF4) of the Pedro Leopoldo Member at the São José da Lapa area.

\begin{tabular}{|c|c|c|c|c|c|c|c|c|c|c|c|}
\hline Clast & $\begin{array}{c}\text { Azimuth } \\
\left({ }^{\circ}\right) \\
\end{array}$ & Clast & $\begin{array}{c}\text { Azimuth } \\
\left({ }^{\circ}\right) \\
\end{array}$ & Clast & $\begin{array}{c}\text { Azimuth } \\
\left({ }^{\circ}\right) \\
\end{array}$ & Clast & $\begin{array}{c}\text { Azimuth } \\
\left({ }^{\circ}\right) \\
\end{array}$ & Clast & $\begin{array}{c}\text { Azimuth } \\
\left({ }^{\circ}\right) \\
\end{array}$ & Clast & $\begin{array}{c}\text { Azimuth } \\
\left({ }^{\circ}\right) \\
\end{array}$ \\
\hline 1 & 110 & 25 & 32 & 49 & 29 & 73 & 95 & 97 & 80 & 121 & 330 \\
\hline 2 & 120 & 26 & 0 & 50 & 125 & 74 & 80 & 98 & 345 & 122 & 5 \\
\hline 3 & 356 & 27 & 322 & 51 & 25 & 75 & 140 & 99 & 29 & 123 & 75 \\
\hline 4 & 15 & 28 & 340 & 52 & 0 & 76 & 20 & 100 & 35 & 124 & 355 \\
\hline 5 & 2 & 29 & 109 & 53 & 8 & 77 & 100 & 101 & 85 & 125 & 340 \\
\hline 6 & 22 & 30 & 322 & 54 & 5 & 78 & 15 & 102 & 50 & 126 & 30 \\
\hline 7 & 2 & 31 & 84 & 55 & 322 & 79 & 70 & 103 & 320 & 127 & 34 \\
\hline 8 & 50 & 32 & 65 & 56 & 106 & 80 & 340 & 104 & 93 & 128 & 110 \\
\hline 9 & 25 & 33 & 70 & 57 & 109 & 81 & 80 & 105 & 85 & 129 & 332 \\
\hline 10 & 0 & 34 & 23 & 58 & 75 & 82 & 20 & 106 & 90 & 130 & 100 \\
\hline 11 & 335 & 35 & 0 & 59 & 75 & 83 & 30 & 107 & 45 & 131 & 300 \\
\hline 12 & 10 & 36 & 15 & 60 & 340 & 84 & 130 & 108 & 130 & 132 & 94 \\
\hline 13 & 20 & 37 & 350 & 61 & 345 & 85 & 110 & 109 & 325 & 133 & 90 \\
\hline 14 & 10 & 38 & 355 & 62 & 110 & 86 & 80 & 110 & 320 & 134 & 0 \\
\hline 15 & 80 & 39 & 8 & 63 & 120 & 87 & 45 & 111 & 350 & 135 & 40 \\
\hline 16 & 55 & 40 & 82 & 64 & 105 & 88 & 45 & 112 & 90 & 136 & 35 \\
\hline 17 & 88 & 41 & 0 & 65 & 45 & 89 & 20 & 113 & 135 & 137 & 75 \\
\hline 18 & 100 & 42 & 90 & 66 & 100 & 90 & 350 & 114 & 25 & 138 & 0 \\
\hline 19 & 330 & 43 & 55 & 67 & 95 & 91 & 20 & 115 & 65 & 139 & 350 \\
\hline 20 & 69 & 44 & 55 & 68 & 110 & 92 & 35 & 116 & 0 & & \\
\hline 21 & 359 & 45 & 5 & 69 & 350 & 93 & 60 & 117 & 90 & & \\
\hline 22 & 119 & 46 & 47 & 70 & 120 & 94 & 60 & 118 & 10 & & \\
\hline 23 & 105 & 47 & 12 & 71 & 330 & 95 & 65 & 119 & 15 & & \\
\hline 24 & 119 & 48 & 42 & 72 & 355 & 96 & 350 & 120 & 95 & & \\
\hline $\begin{array}{c}\text { Range } \\
\left({ }^{\circ}\right) \\
\end{array}$ & $\begin{array}{c}\text { Total } \\
(\%) \\
\end{array}$ & $\begin{array}{c}\text { Range } \\
\left({ }^{\circ}\right) \\
\end{array}$ & $\begin{array}{c}\text { Total } \\
(\%) \\
\end{array}$ & $\begin{array}{c}\text { Range } \\
\left({ }^{\circ}\right) \\
\end{array}$ & $\begin{array}{c}\text { Total } \\
(\%) \\
\end{array}$ & $\begin{array}{c}\text { Range } \\
\left({ }^{\circ}\right) \\
\end{array}$ & $\begin{array}{c}\text { Total } \\
(\%) \\
\end{array}$ & $\begin{array}{c}\text { Range } \\
\left({ }^{\circ}\right) \\
\end{array}$ & $\begin{array}{c}\text { Total } \\
(\%)\end{array}$ & $\begin{array}{c}\text { Range } \\
\left({ }^{\circ}\right)\end{array}$ & $\begin{array}{c}\text { Total } \\
(\%)\end{array}$ \\
\hline $0-5$ & 7.9 & $60-65$ & 2.1 & $120-125$ & 0.7 & $180-185$ & 0.0 & $240-245$ & 0.0 & $300-305$ & 0.0 \\
\hline $5-10$ & 5.0 & $65-70$ & 2.1 & $125-130$ & 1.4 & $185-190$ & 0.0 & $245-250$ & 0.0 & $305-310$ & 0.0 \\
\hline $10-15$ & 3.6 & $70-75$ & 2.8 & $130-135$ & 0.7 & $190-195$ & 0.0 & $250-255$ & 0.0 & $310-315$ & 0.0 \\
\hline $15-20$ & 3.6 & $75-80$ & 3.6 & $135-140$ & 0.0 & $195-200$ & 0.0 & $255-260$ & 0.0 & $315-320$ & 2.1 \\
\hline $20-25$ & 5.0 & $80-85$ & 2.9 & $140-145$ & 0.0 & $200-205$ & 0.0 & $260-265$ & 0.0 & $320-325$ & 2.1 \\
\hline $25-30$ & 2.9 & $85-90$ & 4.3 & $145-150$ & 0.0 & $205-210$ & 0.0 & $265-270$ & 0.0 & $325-330$ & 2.1 \\
\hline $30-35$ & 3.6 & $90-95$ & 2.1 & $150-155$ & 0.0 & $210-215$ & 0.0 & $270-275$ & 1.4 & $330-335$ & 0.7 \\
\hline $35-40$ & 0.7 & $95-100$ & 2.1 & $155-160$ & 0.0 & $215-220$ & 0.0 & $275-280$ & 0.7 & $335-340$ & 2.8 \\
\hline $40-45$ & 3.6 & $100-105$ & 1.4 & $160-165$ & 0.0 & $220-225$ & 0.0 & $280-285$ & 0.0 & $340-345$ & 2.1 \\
\hline $45-50$ & 2.1 & $105-110$ & 5.0 & $165-170$ & 0.0 & $225-230$ & 0.0 & $285-290$ & 0.7 & $345-350$ & 4.2 \\
\hline $50-55$ & 2.1 & $110-115$ & 0.0 & $170-175$ & 0.0 & $230-235$ & 0.0 & $290-295$ & 0.0 & $350-355$ & 2.1 \\
\hline $55-60$ & 1.4 & $115-120$ & 3.6 & $175-180$ & 0.0 & $235-240$ & 0.0 & $295-300$ & 0.7 & $355-360$ & 1.4 \\
\hline
\end{tabular}

sediments deposited at the outer ramp-slope transition (Fig. $5 \mathrm{~A}-\mathrm{B})$. The nature of deposition of LF1 is hard to interpret due the lack of exposures and good preservation of the rocks at the São José da Lapa section. Diamictites found in distinct places in the southern Bambuí basin that have been called the name Carrancas and the rudite found in the km-30 marker of the MG424 roadway, the former classic Carrancas diamictite, were previously interpreted as glacial in origin (Kuchenbecker et al., 2013, 2016; Rocha-Campos et al., 2011; Babinski et al., 2012), gravity flows associated with basement highs and graben-filling deposits (Uhlein et al., 2012; Tuller et al., 2010), or glaciallyinduced fluvial deposits in incised basement valleys (Vieira et al., 2007). At the São José da Lapa section, it is noteworthy the absence of glacially-generated diagnostic features typical of direct ice-contact deposits (i.e., tills) such as boulder pavements, associated meltwater deposits, and striated and glacially-shaped clasts. The nature of the matrix, the geometry of the deposits and the association with LF2 suggests fluvial-induced gravity flows filling a palaeochannel or canyon that incised on the Archean basement (Fig. 5A). LF2 is interpreted as lime muds deposited in relatively quiet environments at the transition between the slope and the deep-outer ramp, as show the absence of sediment gravity flows and storm deposits (Fig. 5B). The lithofacies association successions LFA-2 and LFA-3 are interpreted as the result of sediment gravity flows through a carbonate-dominated ramp slope (Fig. 5C-E). Such deposits are confirmed by lenticular shape of beds, erosional surfaces, poor grading, and a shear zone (Shanmugan, 2000). Lithofacies associations 2 and 3 (LFA2 to LFA3), comprising calcareous arenite (LF3), conglomerate (LF4), calcilutite (LF5) and calcirudite (LF6) lithofacies, are common for the transport of semi-lithified sediments associated through subaqueous channels or canyons that lead to submarine fans of debris flows along the passive margin (Shanmugan, 2000). LF3 comprises grain flow deposits formed by small-scale sliding along a steepened slope (Fig. 5C). Grain flows are characterized by massive bedding, sharp top and bottom bedding surfaces, and presence of reverse grading, as a result of the kinetic sieving effect (Middleton, 1970). LF4 is related to mass-flow downslope movements under the influence of gravity on such a steepened metastable slope (Fig. 5D). The presence of a shear zone at the base of the conglomerate bed exhibits a high stress accompanied by an upward decrease in strain intensity. Such deformation 


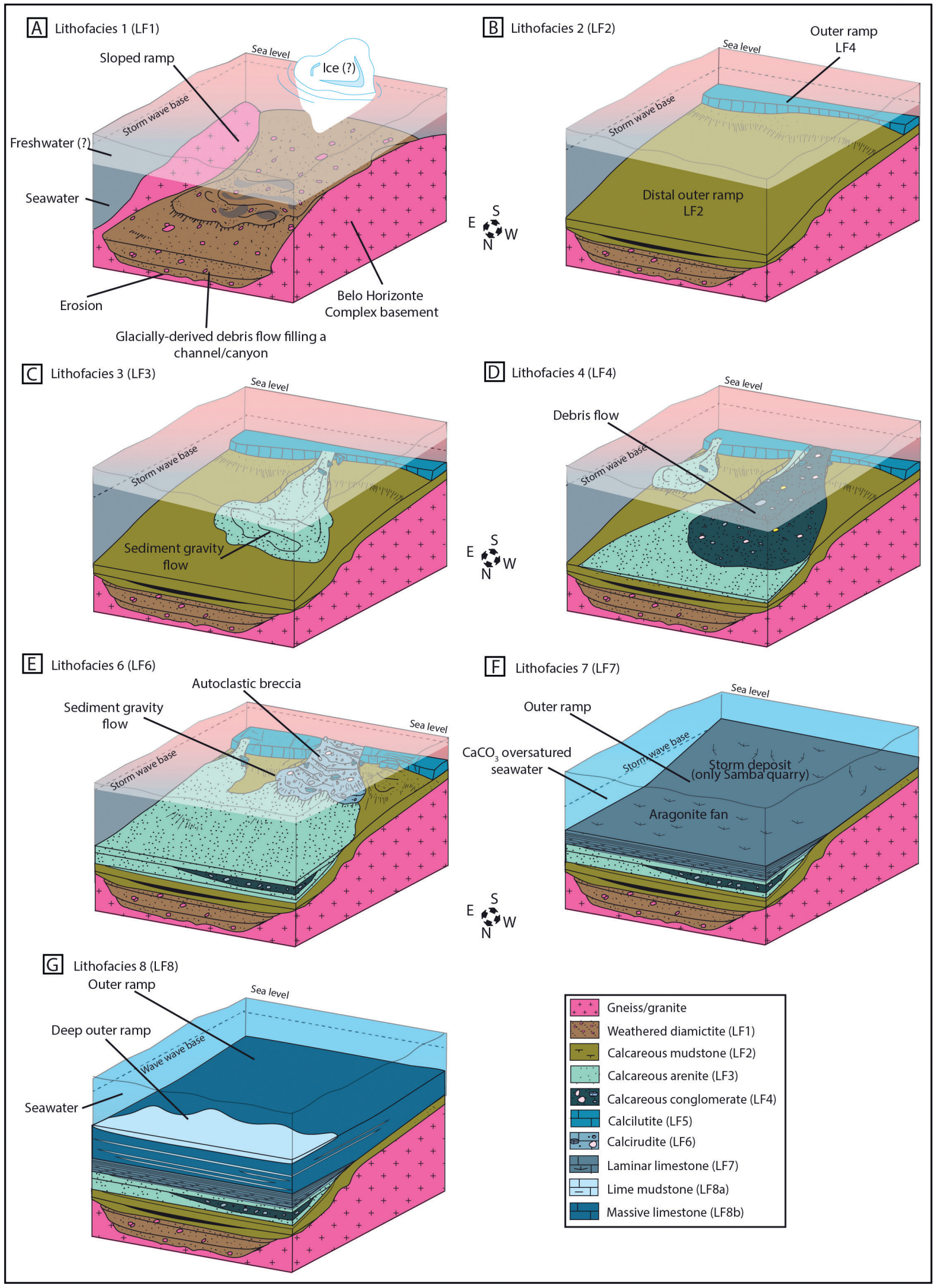

Figure 5. Reconstruction of depositional environments of the Pedro Leopoldo Member, lowermost unit of the Sete Lagoas Formation. The idealized 3D model illustrates the spatial and vertical distribution of a single regressive sequence, succeeding a marine transgression marked by the deposition of the mixed siliciclastic-carbonate succession of the basal Pedro Leopoldo Member, in a slope-outer to outer ramp system. No vertical scale intended. (A) Fluvial-generated sediment gravity flows (LF1) deposited in a N-NE-oriented incised basement valley over the Belo Horizonte Complex during a regressive system tract. The sea-level fall was related to a possible regional glaciation that accumulated the diamictite of the Carrancas Formation. (B) Deposition of calcareous mudstone (LF2) in a distal outer ramp system during the initial stage of a sea-level rise. (C) Sediment gravity flow deposits composed of calcareous arenite (LF3) accumulated above storm wave base deep outer to slope-outer ramp. (D) Debris flow downslope movement (LF4) under the influence of gravity on slope-outer ramp. (E) Slumping and sliding of semi-lithified calcilutite (LF5), forming autoclastic breccia and calcirudite (LF6), on the outer ramp of a low-energy deeper carbonate ramp, periodically submitted to storm wave base environments. (F) Lime mudstone with precipitation of aragonite pseudomorph crystal fans (LF7) in $\mathrm{CaCO}_{3}$ oversaturated marine dysoxic/anoxic waters above storm wave base in an outer carbonate ramp. (G) Lime mudstone and massive limestone (LF8) accumulated in a well-oxygenated low-energy outer-to-middle carbonate ramp (LF8). Notice that the LF1 to LF6 were deposited in a brine-seawater bottom water under suboxic/anoxic conditions (grey to greenish facies) in the relatively deeper portion of the carbonate ramp system during a transgressive system tract occurred in the aftermath of the Marinoan glaciation, while the LF7 and LF8 were formed in well-oxygenated waters during a highstand system tract. 
structures are characteristic of sediment gravity flow deposits, where the water pressure is in excess of the hydrostatic pressure and, thus, reduces the shear strength of the material, which may even be liquefied (Lachniet et al., 2001). LF5 corresponds to a quiet energy distal outer ramp setting with deposition of lime muds below storm wave base environments. LF6 is attributed to slow creep, slumping and sliding of semi-lithified carbonates, forming autoclastic breccia, on the outer margins of a low-energy deeper carbonate ramp similar to ancient submarine fans from northern Appenines (Mutti \& Ricci Lucchi, 1978) (Fig. 5E). Pressure solution processes, occurred by the overloading of sediment gravity flow currents, are highlighted by microstylolites around individual nodules.

Lithofacies association 4 (LFA-4) is interpreted as relatively deep outer ramp deposits (Figs 5F, G). LF7 is interpreted as a result of marine transgression with deposition of lime muds in calcium carbonate oversaturated marine dysoxic/anoxic waters. LF7 is marked by the absence of storm-dominated structures, and the cycle of deposition, which point to quiet energy lime muds settling below storm wave base environments (Fig. 5F). Such facies is laterally deposited on moderate energy tide- and wave-influenced environments along a wide epeiric platform (Vieira et al., 2015). The occurrence of aragonite pseudomorph crystal fans points the proximity with deeper water environments under dysoxic/anoxic waters conditions below storm wave base environments, marked by the transition between the middle and outer ramp (Fig. 5F). The lenticular shape suggests that either the sediments filled a wide depression, which were probably influenced by local differences in the regional tectonics (Reis \& Suss, 2016), possibly enhanced by glacio-isostatic rebound along the shoreline (Vieira et al., 2015; Uhlein et al., 2016).

The balance of evidence such as the absence of moderate- to high-energy sedimentary features, the low-relief erosion at the base of the LF7 beds, and the pinch out of the lenticular beds on the overlying beds, suggests relatively deep-water environments below storm wave base, probably marked by small-scale slumps from distal outer ramp. The cycles are considered as the results of local sliding events, followed by calm periods favouring the lime mud decantation and the precipitation of aragonite pseudomorph crystal fans under dysoxic/axic waters conditions (see Crockford et al., 2018). LF8 represents quiet environments in a distal outer to middle ramp system as show the deposition of lime mudstone (LF8a) and massive limestone (LF8b), as well as the lack of sedimentary features (Fig. 5G). The occurrence of sandy limestone (LF8c) is interpreted as subtidal-intertidal sands seaward reworked to a middle ramp environment.

\section{Discussion}

\subsection{Stratigraphic evolution of the Pedro Leopoldo Member}

The basal Bambuí Group in the south portion of the Sete Lagoas High domain has been extensively studied for stratigraphy, facies and sequence stratigraphy analyses, and depositional conditions (e.g., Costa \& Branco, 1961; Romano \& Knauer, 2003; Romano, 2007; Vieira et al., 2007, 2015; Tuller et al., 2010; Kuchenbecker et al., 2013, 2016; Uhlein et al., 2012, 2016, 2019; Perrella et al., 2017; Paula-Santos et al., 2018; Caetano-Filho et al., 2019; Hippert et al., 2019). In Figure 6, six outcrop and core sections in the Carrancas Formation and Pedro Leopoldo Member strata were examined in Cauê quarry, Mata Grande quarry, Ilcom quarry, Sambra quarry and São José da Lapa, north and northwest Belo Horizonte, and Arcos, southeast Divinopolis. The strata succession shows significant lateral variations of facies in ramp settings, including a wide range of sub-environments. Across the entire outcrop sections, the lower boundary displays an unconformity due to an erosion surface between the ArcheanPaleoproterozoic basement and the Bambuí Group. Above this unconformity, the Bambuí Group sediments show significant lateral variations of facies and thickness that is marked by the non-deposition of the Carrancas diamictite, calcareous mudstone, calcirudite, calcareous conglomerate and calcilutite at Cauê quarry, Mata Grande quarry, Ilcom quarry and Sambra quarry. In Arcos and São José da Lapa, the Carrancas Formation displays less than $1 \mathrm{~m}$-thick diamictite facies that was deposited as a lodgement tillite (Kuchenbecker et al., 2013, 2016; RochaCampos et al., 2011), evolving laterally to glacio-fluviallygenerated gravity flow sediments filling an incised channel on the basement. The Carrancas diamictite gradually grades into: (1) in Arcos, $\sim 9$ m-thick impure limestone, composed of poorly sorted subangular to angular sand- to granule-sized fragments of quartz, granite, schist and carbonate rocks, interbedded by thin calcilutite

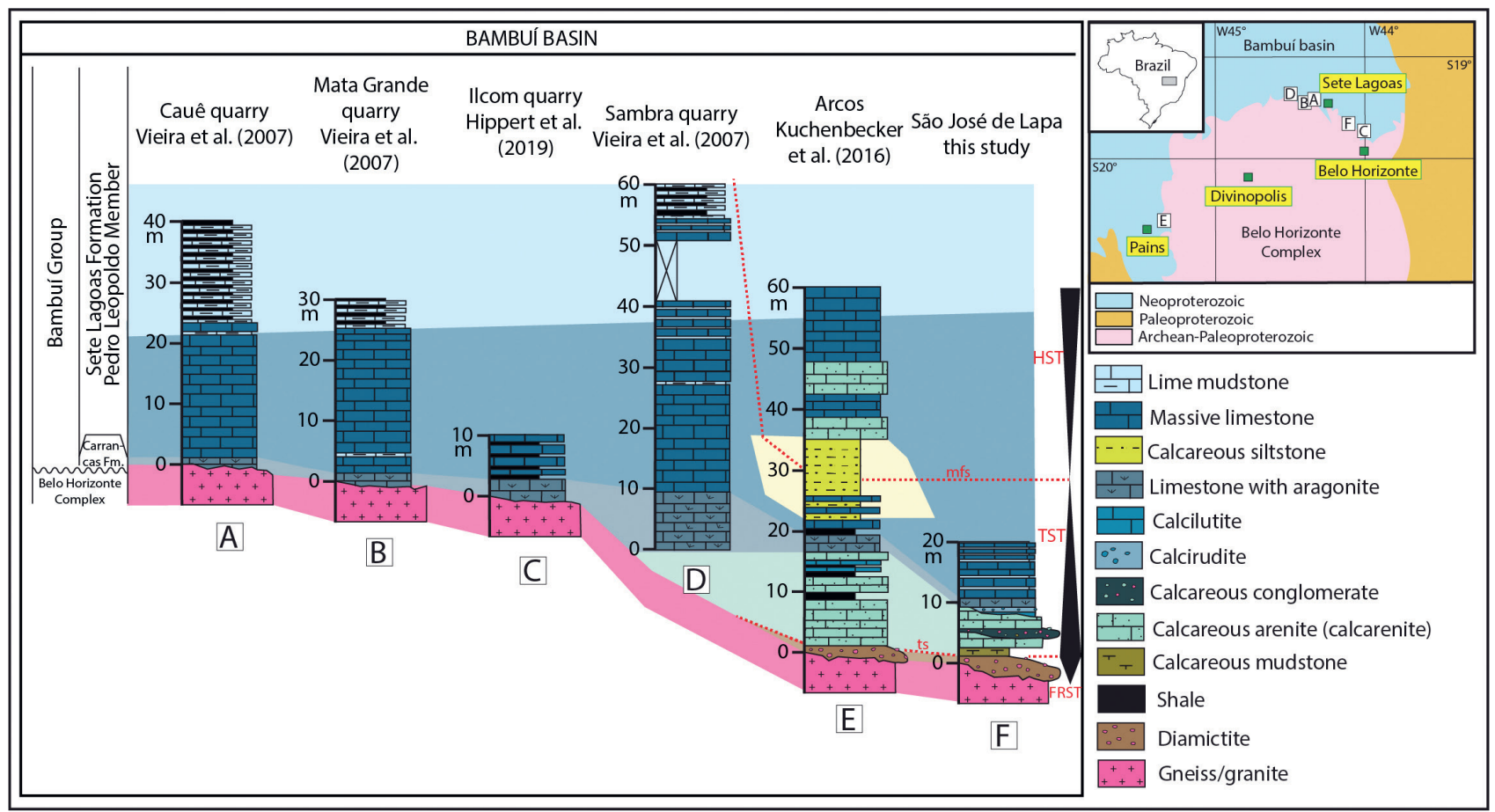

Figure 6. Depositional profile showing the lateral variation of facies in the lower part of the Pedro Leopoldo Member, south Sete Lagoas Basement High. Notice the variation of palaeobathymetry from shallow facies (Caue quarry, Mata Grande quarry, Ilcom quarry), that display lime mudstone with aragonite pseudomorph crystal fans overlain by alternation of lime mudstone and massive limestone unconformably resting on the Belo Horizonte Complex, and the deeper facies (Sambra quarry, Arcos, São José da Lapa), that show distinct lateral variation of facies composed of lenticular beds of calcareous mudstone, calcirudite (calcareous arenite in the study), calcareous conglomerate, calcilutite and calcirudite. Shallower facies represent middle ramp, while deeper facies were deposited near or above storm wave base environments in an outer- to outer-slope ramp. Abbreviations: ts, transgressive surface; mfs, maximum flooding surface; FRST, forced regressive system tract; TST, transgressive system tract; HST, highstand system tract. 
in Arcos (Kuchenbecker et al., 2013, 2016), and (2) in São José da Lapa, $4 \mathrm{~m}$-thick succession of calcareous mudstone at the base, passing to medium- to coarse-grained calcareous arenite, composed of angular fragments of limestone and quartz in roughly equal proportions, interbedded by a $\sim 40 \mathrm{~cm}$-thick lenticular calcareous conglomerate, composed of subangular to subrounded sand- to pebble-sized fragments of limestone, sandstone, quartz, granite and gneiss. Both sections are overlain by a 1 to $8 \mathrm{~m}$-thick succession of calcilutite, calcarenite and 1 to $2 \mathrm{~m}$-thick lenticular calcirudite composed of subangular to subrounded granule- to pebble-sized fragments of limestone. At São José da Lapa, the bed geometry shows lenticular shapes for this succession. The sedimentary succession records a lateral variation of facies that was marked by an abrupt shift from glacio-fluvial to marine ramp environments. This transition recorded a retrogradational pattern of a mixed siliciclastic-carbonate system during a transgressive system tract that slowly landward progressed on the Sete Lagoas High, as shown by the erosion surface and the absence of this sequence in the Caue quarry, Mata Grande quarry, Ilcom quarry and Sambra quarry. The sequence recorded a middle to outer ramp system, connected to slope-outer ramp system that deposited on gravitational flow sediments, oriented N-NE, in incised valleys. The mixed siliciclastic-carbonate system was the result of a reorganization of drainage patterns on a carbonate ramp system that was related to a regional flexure promoted by reactivation on the São Francisco Craton, generating forebulge grabens in the basin (Reis \& Suss, 2016), possibly coupled with a glacial-isostatic rebound. Overall sections are marked by the deposition of 0.3 to $9 \mathrm{~m}$-thick laminar limestone with single to multiple planar parallel layers of aragonite pseudomorph crystal fans, overlain by metre-scale alternations of lime mudstone and massive limestone. The disturbed arrangement of aragonite pseudomorph crystal fans at Sambra quarry probably recorded a storm wave base environment in a $\mathrm{CaCO}_{3}$ oversaturated deep middle ramp system under dysoxic/anoxic waters conditions (Vieira et al., 2007, 2015; Crockford et al., 2018, 2019), which separated the shallower facies (above storm wave base; middle ramp) at Cauê quarry, Mata Grande and Ilcom quarries from the deeper facies (below storm wave base; outer ramp) at Arcos and São José da Lapa. However, recent publications proposed that the aragonite pseudomorph crystal fans were deposited on low to moderate energy tide- and wave-influenced environments, free from significant terrigenous supply, along a wide epeiric platform (Vieira et al., 2015; Okubo et al., 2018). In Arcos, Kuchenbecker et al. (2013) argued the presence of storm-oscillatory flow structures in the impure limestone overlying the laminar limestone that suggest that the carbonate muds were deposited near storm wave base environments. Similar facies, composed of thin alternations of lime mudstone and massive limestone, are observed at São José da Lapa. However, no sedimentary structures related to storm deposits are observed, which indicate that the sediments were deposited in relatively quiet energy below storm wave base environment in an outer ramp system. In term of eustatic sea-level evolution, the marine transgression rapidly turned off the supply of siliciclastic materials for the production of carbonate muds on the storm-dominated deep middle and outer parts of the carbonate ramp system. The maximum flooding surface was recorded in the shale/mudstone outer ramp facies in Arcos, that initiated a sea-level highstand stage and the development of retrogradational-progradational staking patterns of lime mudstone and massive limestone deposited in a middle ramp system (Caetano-Filho et al., 2019). At Vespasiano, the facies succession forms a shallowing-upward sequence, marked by the deposition of middle ramp sandy limestone that seaward reworked subtidal-intertidal sands from shallow middle and inner ramp system.

The sediments at the classic type section of the "Carrancas Formation" outcrop at km 30 of the MG-424 road at São José da Lapa are misinterpreted because: (1) the diamictite facies of the Carrancas Formation is approximately 5 m-thick below the calcareous conglomerate, which is erroneously interpreted as the Carrancas Formation, (2) the calcareous conglomerate interbeds $\sim 10 \mathrm{~m}$-thick of sediment gravity flow succession that are semiconsolidated mixed siliciclastic-carbonate sediments accumulated on a broad channel or canyon incising the basement - and in general the envisaged deep-water sedimentary environment, and (3) the debris flow deposits were occurred during a marine transgression, which reworked sediments from the proximal ramp into the basin by sediment gravity flow currents due to the hydraulic instability created by rapidly increasing water depths.

\subsection{Pedro Leopoldo Member: A cap carbonate sequence?}

The basal Bambuí Group in the Sete Lagoas High shows different patterns of facies than the carbonate rocks in the Januária High (Fig. 7). The basal Bambuí Group in the Januária-Itacarambi region differs from the facies in the Sete Lagoas High by up to $100 \mathrm{~m}$-thick tidal flat-like cap carbonate sequence that is composed, from the base to the top, of 2-5 m-thick massive to finely laminated pink to white-buff dolostone overlying by $20-\mathrm{m}$ thick light grey to pinkish-red laminated to peloidal limestone with single to multiple layers of aragonite crystal fan pseudomorphs, and $125 \mathrm{~m}$-thick reddish limestone rhythmite

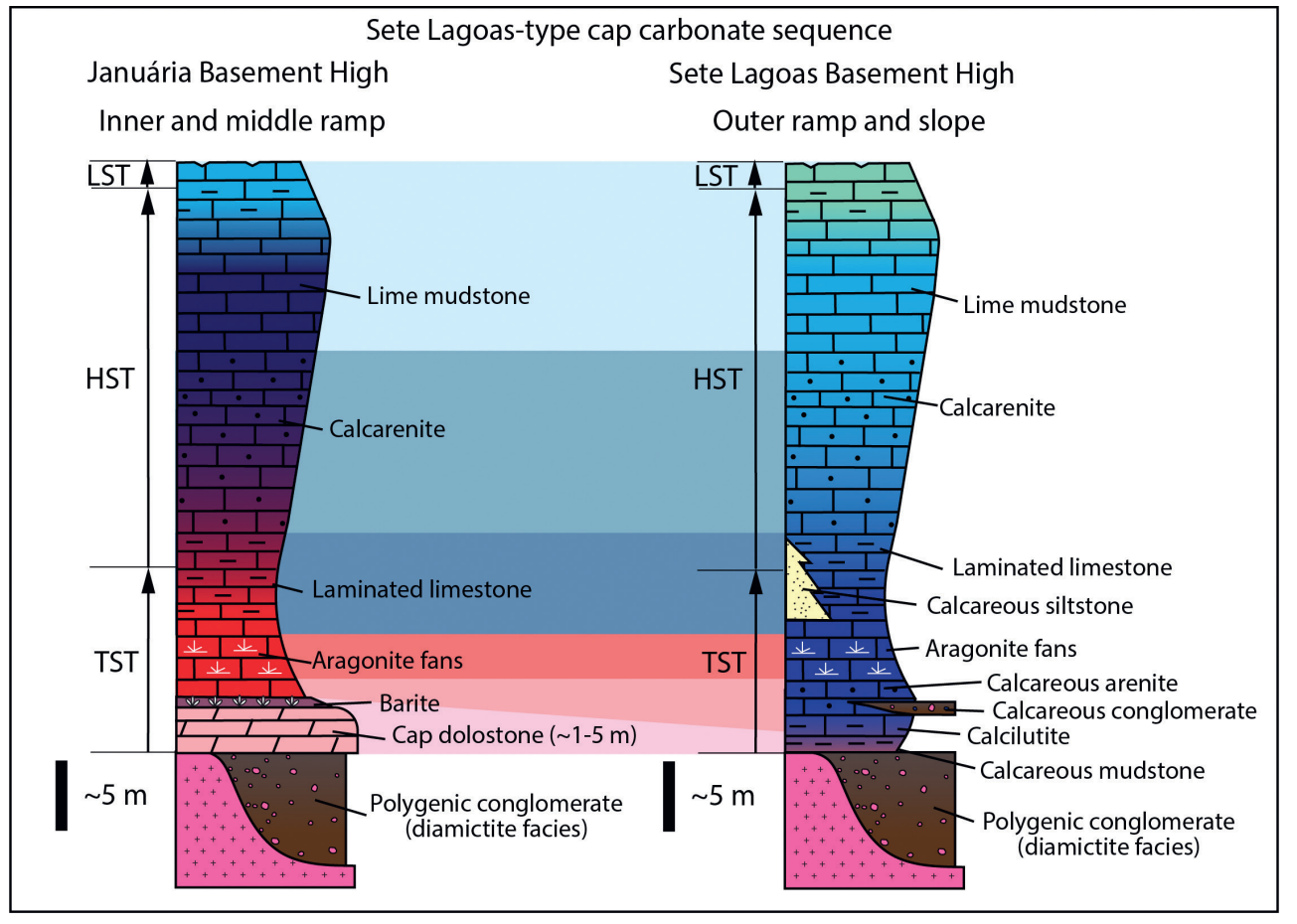

Figure 7. Idealized cap carbonate sequence at the Januária section area, Januária Basement High (data from Caxito et al., 2018; Caetano-Filho et al., 2019) showing a lateral variation of facies with the basal Pedro Leopoldo facies south Sete Lagoas Basement High. The cap carbonate sequence shows a deepeningupward transgressive system tract formed by tidal flat-like pink-grey laminated dolostone of shallow waters, laterally passing to outerto-outer-slope ramp calcareous mudstone and calcareous arenite in the deeper portion of the basin. All facies are capped by limestone with aragonite pseudomorph crystal fans, locally barite, and laminated limestone accumulated near a highstand system tract. Calcarenite and lime mudstone were accumulated during a sealevel highstand. Abbreviations: LST, lowstand system tract; TST, transgressive system tract; HST, highstand system tract. 
composed of centimetre-scale calcilutite and marly siltstone, locally green shale partings, with plane-parallel and crossed laminations (Fig. 7; Iglesias \& Uhlein, 2009; Caxito et al., 2012, 2018; Caetano-Filho et al., 2019). The sequence is capped by $\sim 80$ m-thick black laminated calcarenite with chert nodules, hummocky and crossed laminations (Iglesias \& Uhlein, 2009). The cap carbonate sequence in the Januária-Itacarambi region shows a typical carbon isotope signature, with values from $-3.8 \%$ o to $-4.2 \%$, that has been interpreted by Caxito et al. (2012) as an Ediacaran cap dolostone related to the Marinoan glaciation worldwide. In the Sete Lagoas High, carbon isotope values at the basal Sete Lagoas Formation displays the same negative excursion with values close to $-4.0 \%$ o to $-5.5 \%$ with a recover to $0 \%$ near the maximum flooding surface (Caetano-Filho et al., 2019). Regarding the carbon isotope evolution at the base of the Bambuí Group as coeval in age, the cap carbonate sequence in the Januária-Itacarambi region displays a lateral variation of facies in regard to the facies in the north Belo Horizonte region (Fig. 7). In the Sete Lagoas High, the pink dolostone appears to be missing (no deposition or eroded?), that seaward passes to outer ramp calcareous mudstone and calcilutite facies. Local gravity flow sediments developed from the deep outer ramp system to the toe of a distally steepened slope. Laminated to peloidal limestone in the Januária High seaward evolved to stormgenerated middle-outer ramp laminated limestone with single to multiple layers of aragonite crystal fan pseudomorphs in the Sete Lagoas High. The pink to red variation of colours probably reflected the redox conditions in the water column during possible deglaciation, which occurred stable density stratification with oxygenated mixed layer and intermediate water near the surface water and brine-seawater bottom water under suboxic/anoxic conditions (grey to greenish facies) in the relatively deeper portion of the carbonate ramp system. The conditions enhanced the development of barite and aragonite crystal fans in alkaline oversaturated environments under strong stratified post-glacial ocean (Crockford et al., 2018, 2019; Okubo et al., 2018). The transition from sea-level transgressive to highstand sequences was marked by a maximum flooding surface that recorded the return of widespread development of carbonate sediments through the basin. Facies in the Januária and Sete Lagoas highs appears to be coeval, and consist of middle to inner ramp laminated limestone, calcarenite and lime mudstone.

\subsection{Interbasinal correlation}

The cap carbonate sequence of the basal Bambuí Group recorded a worldwide ultra-greenhouse event that could be correlated with other basins. In this paper, the basal Bambuí Group is correlated with the post-Marinoan cap carbonate sequences of the $\sim 635-575$ Ma Schisto-Calcaire/Lukala (Sub)Group of the West Congo Belt in western Central Africa (Gabon, Republic of Congo or RC, Democratic Republic of the Congo or DRC, and Angola) (Frimmel et al., 2006; Straathof, 2011; Fullgraf et al., 2015) and the $\sim 627-570$ Ma Araras Group of the Paraguay Belt in central-western Brazil (Cordani et al., 1978; Babinski et al., 2006; Romero et al., 2013) (Fig. 8). The West Congo Belt was connected with the Bambuí basin region during the Neoproterozoic (Pedrosa-Soares et al., 2001, 2008; Alkmim et al., 2006; Pedrosa-Soares \& Alkmim, 2011; Evans et al., 2016), while the Paraguay Belt was located on the margin of the Amazonia Craton facing the Kalahari and Congo cratons (Li et al., 2013). The basal Schisto-Calcaire/Lukala (Sub)Group strata succession shows significant lateral variations of facies in ramp settings accumulated during transgressive system tract, including a wide range of sub-environments such as shallow-water middle ramp, storm-generated outer ramp, gravity sediment flows and turbidity currents on steepened slope, and deep water turbidites at slope toe (Fig. 8A; Alvarez \& Maurin, 1991; Alvarez, 1995; Prian et al., 2009; Thiéblemont et al., 2009; Préat et al., 2011; Mickala et al., 2015; Delpomdor et al., 2016, 2019). At the base of the Schisto-Calcaire/Lukala (Sub)Group, a 0 to $15 \mathrm{~m}$-thick pink to grey, locally buff, thinly laminated peloidal dolostone, similar to the cap dolostone in the Januária-Itacarambi region in Brazil, unconformably rests on the Niari Group conglomerate in Gabon, which seaward passes to diamictites of the Upper Diamictite Formation in RC and DRC. In Gabon and RC, the cap dolostone displays middle to outer ramp facies including stromatolites and hummocky cross-laminations, giant wave ripples (Préat et al., 2011; Mickala et al., 2015), while, in DRC, the unit shows deep-water Bouma-type doloturbidites (Delpomdor et al., 2016, 2019). The transgression ends with the accumulation of outerramp red dolomitic marl to marly siltstone (Prian et al., 2009; Thiéblemont et al., 2009) and 20 m-thick rust-coloured to purple deep-water slope-to-outer-ramp rhythmites, composed of graded muddy dolostone and silty claystone, and Bouma-type turbidite sequences, composed of graded sandstone and claystone (Delpomdor et al., 2016), in the proximal and distal portions of the basin. A sea-level highstand begins with the deposition of 20 to $40 \mathrm{~m}$-thick red-brick silty and dolomitic shale, cross-laminated pink silty dolostone with thin shale partings, and dolostone with aragonite pseudomorph crystal fans in Gabon and RC (Prian et al., 2009; Préat et al., 2011) and up to 100 m-thick red-brick to green silty and dolomitic shale, siltstone and sandstone that are capped by brown laminated calcarenite beds with mega-scale hummocky cross-laminations in DRC (Delpomdor et al., 2016). In central-western Brazil, the Araras Group shows similar lateral variations of facies that were accumulated in an inner shelf to outer shelf, including storm-wave influenced facies, and slope intraformational breccia during a transgressive system tract in the aftermath of the Marinoan glacio-marine deposits of the Puga Formation (Fig. 8B; Sansjofre et al., 2014). A pink to grey thinly laminated cap dolostone of the Mirassol d'Oeste Formation including stromatolite, tube-like structures and mega-ripples is overlain by grey limestone and sandstone of the Guia Formation comprising multiple layers of aragonite pseudomorph crystal fans, and dolostone and limestone of the Serra do Quilombo and Nobres formations respectively (Nogueira et al., 2007; Sansjofre et al., 2014). Neoproterozoic cap carbonate sequences worldwide display distinct sedimentological facies such as fine laminations, tube-like structures, mega-ripples that were accumulated during a transgressive system tract in the global aftermath of post-glacial sea-level rise. However, the synchronicity of deposition remains a matter of debate. Cap carbonates show a lateral variation of carbon isotope values that vary from place to place. The different $\delta^{13} \mathrm{C}$ variations in the cap carbonates were explained by diachronous carbonate production related to surface warming, methane release, and kinetic isotope effects during deglaciation (Hoffman et al., 2007). Diachroneity was also interpreted as the lateral variation of depositional environments in a stratified ocean, which higher $\delta^{13} \mathrm{C}$ values occurred in the proximal environment compared to those in distal settings (Shen et al., 2005; Jiang et al., 2010). In the Bambuí basin, the $\delta^{13} \mathrm{C}$ values in the carbonate sequence range from $-3.8 \%$ to $-4.2 \%$ in the tidal flat facies (Caxito et al., 2012,2018 ), from $-3.0 \%$ to $-6.5 \%$ in the outer ramp facies in the Januária High (Caetano-Filho et al., 2019), laterally varying from $-4.0 \%$ to $-5.5 \%$ in the deep outer ramp facies in the Sete Lagoas High, with a recover to $0 \%$ in the middle-inner ramp facies in the upper portion of the Sete Lagoas Formation in both basement high domains (Caetano-Filho et al., 2019). In the West Congo Belt in Central Africa, the cap carbonate sequence of the basal Schisto-Calcaire/Lukala (Sub)Group shows a similar variation of $\delta^{13} \mathrm{C}$ values related to lateral variation of facies from shallow to deep environments: (1) from $-2.5 \%$ to $-4.0 \%$ in lagoonal cap carbonate facies from RC (Mickala et al., 2014); (2) from $-2.8 \%$ to $-3.5 \%$ in storm-generated cap carbonate facies with a recover to $+5.4 \%$ in the middle-inner ramp facies in Gabon (Préat et al., 2011); (3) from $-3.4 \%$ to $-5.8 \%$ in the slope-outer ramp cap carbonate and rhythmite facies with a recover to $0 \%$ in the inner ramp facies in DRC (Frimmel et al., 2006; Straathof, 2011; Delpomdor \& Préat, 2013). In central-western Brazil, the Araras Group of the Paraguay Belt displays a negative excursion with $\delta^{13} \mathrm{C}$ values close to $-10.5 \%$ to $-2.7 \%$ and $-8.7 \%$ o to $-4.7 \%$, respectively, in the relatively deeper and shallow facies of the Mirassol d'Oeste Formation (Alvarenga et al., 2004; Font et al., 2006; Nogueira et al., 2007), that are considered as cap carbonate deposits, with a recover to $0 \%$ in the tidal flat carbonates of the Serra do Quilombo and Nobres formations (Nogueira et al., 2007; Rudnitzki et al., 2016). In regard to these results, the $\delta^{13} \mathrm{C}$ values seem to be dependent of lateral variations of facies and their subenvironments, which display higher and lower $\delta^{13} \mathrm{C}$ values in the shallower and deeper environments forming a diachronous 


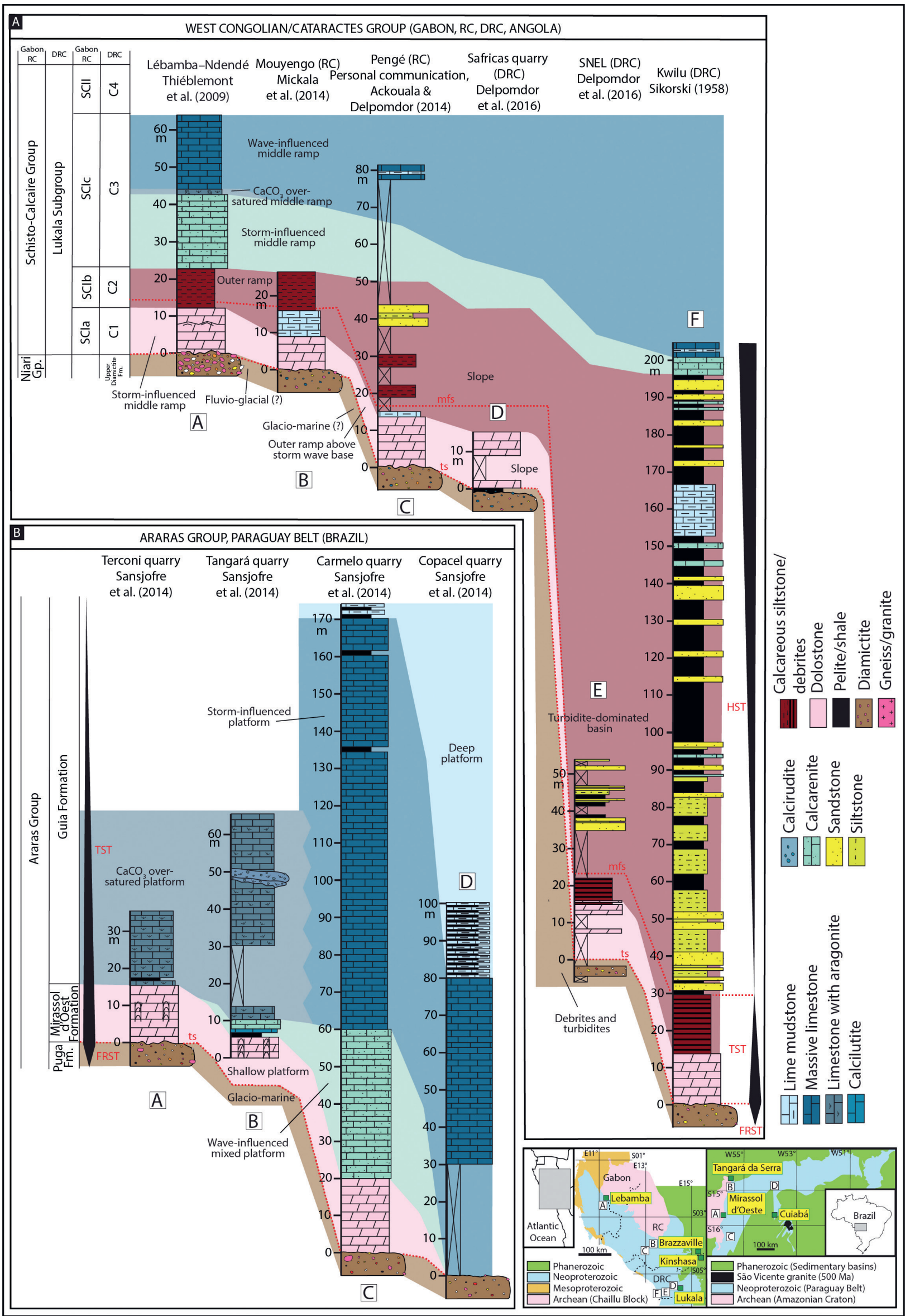

Figure 8. Example of lateral variation of facies in neighbouring basins in the West Congo and Paraguay belts. (A) The basal Schisto-Calcaire/Lukala (Sub)Group of the West Congo Belt, Central Africa, shows a distinct lateral variation of facies that consists, from the shallower to the deeper portion of the basin, of storm-generated pink-grey-white laminated dolostone with giant ripples, accumulated on a middle-outer ramp, passing to doloturbidites and debrites deposited on slope environments. Dolomitic siltstone laterally evolves to deep-water Bouma-type turbidites. (B) The basal Araras Group of the Paraguay Belt, central-western Brazil, shows similar lateral variations of facies than the Schisto-Calcaire/Lukala (Sub)Group of the West Congo Belt and the basal Bambuí Group. The basal Araras Group were accumulated in an inner shelf to outer shelf, including storm-wave influenced facies, and slope intraformational breccia during a transgressive system tract in the aftermath of the Marinoan glacio-marine deposits of the Puga Formation. Abbreviations: ts, transgressive surface; mfs, maximum flooding surface; FRST, forced regressive system tract; TST, transgressive system tract; HST, highstand system tract. Data for Pengé (Republic of Congo) is referenced in Ackouala, A.-P. \& Delpomdor, F., 2014. Mission de terrain dans la région des boucles du Niari du 13 janvier au 4 février 2014. Communication personnelle. All data are available upon request. 
depositional setting for the cap carbonate sediments.

The basal Bambuí Group, represented by the Pedro Leopoldo Member, recorded relative sea-level fluctuations occurred though the extensional reactivation of ancient basement structures along with the tectonically driven forebulge uplift of the Sete Lagoas High, caused by the compressional movements catalysed by the Brasília and Araçuaí orogenic belts, in the early evolutionary stages of the Bambuí Basin cycle (Alkmim \& Martins-Neto, 2001; Martins-Neto et al., 2001; Alkmim et al., 2011; Reis \& Suss, 2016), probably coupled with a glacial-isostatic rebound. The sea-level rise progressed rapidly, directly after the Marinoan glaciation, with the deposition of cap carbonate facies on the shallow portion of the basin, diachronously accumulated with sediment gravity flows on mixed siliciclastic-carbonate slopeouter ramp environments as observed at the base of the Pedro Leopoldo Member at São José da Lapa, then the development of a $\mathrm{CaCO}_{3}$ oversaturated carbonate sedimentation on the basin margin of the Sete Lagoas High.

\section{Conclusions}

The Pedro Leopoldo Member, basal unit of the Bambuí Group, in the Sete Lagoas High has been interpreted as shallowingupward carbonate sequence that was deposited on a ramp system probably in the aftermath of the Marinoan glaciation. Our detailed studies at the São José da Lapa area demonstrates that the classic Carrancas conglomerate in its type section, located at km-30 marker of the MG-424 roadway, actually forms a rudite lens within the basal part of the Pedro Leopoldo Member, instead of a glaciogenic diamictite deposited before the basal carbonate sequence of the Bambuí Group. Re-examination of the outcrop section indicates that the succession bears no fabrics typical of tillites, but represents (possibly post-glacial) redeposited mixed siliciclastic-carbonate materials on a present-day N-NE-trending valley or canyon incised on the Archean basement, in submarine slope-outer ramp environments. In fact, a less than $1 \mathrm{~m}$-thick diamictite-like facies (in our study LF1), strongly weathered, is ascribed to the Carrancas Formation, placed beneath the Pedro Leopoldo Member. This weathered diamictite may be correlated with similar diamictites located in other places of the southern Bambuí basin, which have been interpreted as lodgement tillite (Kuchenbecker et al., 2013, 2016; Rocha-Campos et al., 2011) or gravity flow deposits associated with basement highs and graben-filling deposits (Tuller et al., 2010; Uhlein et al., 2012). In our opinion, the Carrancas diamictite of São José da Lapa was probably formed as a glacially-induced fluvial deposit in an incised valley on the basement. Overall outcrop sections in the Pedro Leopoldo Member display a vertical succession of lithofacies (LF2 to LF8) that records a shallowing-upward evolution up to $30 \mathrm{~m}$-thick sediment gravity flow succession (LF2 to LF6) deposited in slope-outer ramp environments at the base to quiet-energy open marine sediments (LF7 to LF8) below storm-influenced sediments in an outer ramp environment at the top. The sediment gravity flow deposits were formed due the accumulation of instable semi-consolidated clastic sediments mixed with carbonate muds on the deep outer ramp system, which produced sliding and sediment gravity flow currents in relatively deeper waters in a slope ramp system. The sediment gravity flow deposits observed in our working area in the south Sete Lagoas High can be laterally correlated to the cap dolostone of shallowwater origin found in the Januária High, based on the similarity of $\delta^{13} \mathrm{C}$ trends and values in both basement high domains (from $-4.0 \%$ to $-5.5 \%$ in the Sete Lagoas High, and from $-3.8 \%$ to $-4.2 \%$ in the Januária High; see Caxito et al., 2012, 2018; PaulaSantos et al., 2017; Caetano-Filho et al., 2019). The absence of a cap dolostone in Sete Lagoas High could be explained by lack of accommodation space of sediment infill or a regional erosion, which is due to the tectonically driven forebulge uplift of the Sete Lagoas High, related to the uplift of the Brasília and Araçuai belts, initiating the early evolutionary stages of the Bambuí basin cycle (Alkmim \& Martins-Neto, 2001; Martins-Neto et al., 2001; Alkmim et al., 2011; Reis \& Suss, 2016), possibly coupled with a glacial-isostatic rebound. Tectonic movements have initiated a sea-level rise throughout the basin. The end of the marine transgression recorded a turn on of the carbonate production with the deposition of relatively deep-water outer ramp (LF7) and middle ramp (LF8) environments below storm wave base. The rate of sea-level rise decrease, followed by calm periods, favoured the lime mud decantation and the precipitation of aragonite pseudomorph crystal fans under $\mathrm{CaCO}_{3}$ oversaturated dysoxic waters conditions in a probable stratified post-glacial ocean. A cap carbonate sequence could show significant lateral variations of facies, including a wide range of sub-environments that control the $\delta^{13} \mathrm{C}$ variations in shallow- to deep-water carbonate rocks (Shen et al., 2005; Jiang et al., 2010). According these variations, the carbonates of the Pedro Leopoldo Member of the southeast Bambuí basin, correlated with the cap carbonate sequences of the basal Schisto-Calcaire/Lukala (Sub)Group of the West Congo Belt and the basal Araras Group of the Paraguay Belt, are marked by a diachronous carbonate production, which displays higher $\delta^{13} \mathrm{C}$ values occurred in the proximal environment, from $-3.8 \% 0$ to $-4.2 \%$ in the tidal flat facies (see Caxito et al., 2012, 2018), compared to those in distal settings, to $-4.0 \%$ o to $-5.5 \%$ in the deep outer and slope-outer ramp facies (see Caetano-Filho et al., 2019). In conclusion, the Pedro Leopoldo Member can be considered as a part of a cap carbonate sequence that was accumulated in a brine-seawater bottom waters under anoxic conditions in the relatively deeper portion of a carbonate ramp system.

\section{Acknowledgements}

The Conselho Nacional de Desenvolvimento Científico e Tecnológico $(\mathrm{CNPq})$ is thanked for the funding of this study. We are grateful to landowners who kindly allowed us to work in their properties. We thank the reviewers Nick Eyles and Michel Villeneuve for their constructive reviews and helpful criticism. The views, opinions and concepts expressed in this article are the sole responsibility of the authors.

\section{Funding}

FD was supported by Programa Ciência sem Fronteiras-Young Talents Attraction program of CNPq [grant 401240/2014-2]. A.M.I was funded by CNPq [grant BJT-level A No. 314746/20145] and Bolsa Iniciação científica e Tecnológica (BIC) [grant $168076 / 2014-4]$. A.C.P.S and F.A.C. thanks CNPq for the Pq-1B and Pq-2 Research Productivity Grants, respectively.

\section{References}

Alkmim, F.F. \& Martins-Neto, M., 2001. Bacia intracratonica do São Francisco: Arcabouço estrutural e cenários evolutivos. In Pinto, C.P. \& Martins-Neto, M.A. (eds), Bacia do São Francisco: Geologia e Recursos Naturais. SBG/MG, Belo Horizonte, 9-30.

Alkmim, F.F., Marshak, S., Pedrosa-Soares, A.C., Peres, G.G., Cruz, S.C. \& Whittington, A., 2006. Kinematic evolution of the Araçuaí-West Congo orogen in Brazil and Africa: nutcracker tectonics during the Neoproterozoic assembly of Gondwana. Precambrian Research, 149, 43-63. https://doi.org/10.1016/j.precamres.2006.06.007

Alkmim, F.F., Pedrosa-Soares, A.C., Cruz, S.C.P. \& Silva, C.M.T., 2011. Map-view curves of the Brasiliano/PanAfrican Araçuaí and West Congolian belts: Products of craton-orogen interactions during the assembly of West Gondwana. In Schmitt, R.S., Trouw, R., Carvalho, I.S. \& Collins, A. (eds), Gondwana 14, Abstracts. Universidade Federal do Rio de Janeiro, Rio de Janeiro, p. 59

Alvarenga, C.J.S., Santos, R.V. \& Dantas, E.L., 2004. C-O-Sr isotopic stratigraphy of cap carbonates overlying Marinoan-age glacial diamictites in the Paraguay Belt, Brazil. Precambrian Research, 131, 1-21. https://doi.org/10.1016/j.precamres.2003.12.006

Alvarenga, C.J.S., Santos, R.V., Vieira, L.C., Lima, B.A.F. \& Mancini, L.H., 2014. Meso-Neoproterozoic isotope stratigraphy on carbonate platforms in the Brasília Belt of Brazil. Precambrian Research, 251, 164-180. https://doi.org/10.1016/j.precamres.2014.06.011

Alvarez, P., 1995. Les facteurs de contrôle de la sédimentation du Supergroupe Ouest-Congolien (Sud-Congo): rampe carbonatée et activité biologique au Protérozoïque Supérieur. Documents du BRGM, 239, 286 p. 
Alvarez, P. \& Maurin, J.-C., 1991. Evolution sédimentaire et tectonique du bassin protérozoïque supérieur de Comba (Congo): stratigraphie séquentielle du Supergroupe Ouest-Congolien et modèle d'amortissement sur décrochements dans le contexte de la tectogénèse panafricaine. Precambrian Research, 50, 137-171. https://doi.org/10.1016/0301-9268(91)90051-B

Babinski, M., Trindade, R.I.F. \& Alvarenga, R.V., 2006. Geochronological constraints on the Neoproterozoic glaciations in Brazil. In Snowball Earth 2006, Monte Verità, Ticino (Switzerland), 16-21 July 2006. ETH Zurich, Ascona, 19-20.

Babinski, M., Vieira, L.C. \& Trindade, R.I.F., 2007. Direct dating of the Sete Lagoas cap carbonate (Bambuí Group, Brazil) and implications for the Neoproterozoic glacial events. Terra Nova, 19, 401-406. https://doi.org/10.1111/j.1365-3121.2007.00764.x

Babinski, M., Pedrosa-Soares, A.C., Trindade, R.I.F., Martins, M., Noce, C.M. \& Liu, D., 2012. Neoproterozoic glacial deposits from the Araçuaí orogen, Brazil: Age, provenance and correlations with the São Francisco Craton and West Congo belt. Gondwana Research, 21/2-3, 451-465. https://doi.org/10.1016/j.gr.2011.04.008

Babinski, M., Paula-Santos, G.M., Kuchenbecker, M., Caetano-Filho, S., Trindade, R.I. \& Pedrosa-Soares, A.C., 2013. The isotopic record of the Bambui Group, Brazil: Sturtian, Marinoan, and/or Early Paleozoic? AGU Spring Meeting Abstracts, 2013.

Caxito, F.A., Halverson, G.P., Uhlein, A., Stevenson, R., Dias, T.G. \& Uhlein, G.J., 2012. Marinoan glaciation in east central Brazil. Precambrian Research, 203, 38-58. https://doi.org/10.1016/j. precamres.2012.01.005

Caxito, F.A., Uhlein, G.J., Sial, A.N. \& Uhlein, A., 2016. Estratigrafia isotópica de carbono e oxigênio da Formação Jaíba, Grupo Bambuí Superior, Ediacarano da bacia do São Francisco Anais. $48^{\circ}$ Congresso Brasileiro de Geologia, SBG, Porto Alegre, Brazil.

Caxito, F.A., Frei, R., Uhlein, G.J., Gonçalves Dias, T., Bech Árting, T. \& Uhlein, A., 2018. Multiproxy geochemical and isotope stratigraphy records of a Neoproterozoic Oxygenation Event in the Ediacaran Sete Lagoas cap carbonate, Bambuí Group, Brazil. Chemical Geology, 481, 119-132. https://doi.org/10.1016/j.chemgeo.2018.02.007

Caetano-Filho,S., Paulao-Santos, G.M., Guacaneme, C., Babinski, M., Bedoya-Rueda, C., Peloso, M., Amorim, K., Afonso, J., Kuchenbecker, M., Reis, H.L.S. \& Trindade, R.I.F., 2019. Sequence stratigraphy and chemostratigraphy of an Ediacaran-Cambrian foreland-related carbonate ramp (Bambuí Group, Brazil). Precambrian Research, 331, in press. https://doi.org/10.1016/j.precamres.2019.105365

Chiavegatto, J.R.S., Gomes, N.S., Dardenne, M.A. \& Delgado, C.E.R., 2003. Estratigrafia do Grupo Bambuí nas regiões Norte de Minas Gerais: uma nova unidade estratigráfica e um contexto de inversão de bacia. $12^{\circ}$ Simpósio de Geologia de Minas Gerais, Ouro Preto.

Cordani, U.G., Kawashita, K. \& Thomaz Filho, A., 1978. Applicability of the Rubidium-Strontium method to shales and related rocks. In Cohee, G.V., Glaessner, M.F. \& Hedberg, H.D. (eds), Contributions to the Geological Time Scale. AAPG studies in Geology, 6, 93-117. https://doi.org/10.1306/St6398C8

Cordani, U.G., Sato, K., Teixeira, W., Tassinari, C.C.G. \& Basei, M.A.S., 2000. Crustal evolution of the South American Platform. In Cordani, U.G., Milani, E.J., Thomaz Filho, A. \& Campos D.A. (eds), Tectonic Evolution of South America. 31 ${ }^{\text {st }}$ International Geological Congress, Rio de Janeiro, 19-40.

Costa, M.T. \& Branco, J.J.R., 1961. Roteiro para a excursão Belo Horizonte - Brasília. Congresso Brasileiro de Geologia, 14, 15-25.

Crockford, P.W., Cowie, B.R., Johnston, D.T., Hoffman, P.F., Sugiyama, I., Pellerin, A., Bui, T.H., Hayles, J., Halverson, G.P., MacDonald, F.A. \& Wing, B.A., 2016. Triple oxygen and multiple sulfur isotope constraints on the evolution of the post-Marinoan sulfur cycle. Earth and Planetary Science Letters, 435, 74-83. https://doi.org/10.1016/j. eps1.2015.12.017

Crockford, P.W., Hodgskiss, M.S.W., Uhlein, G.J., Caxito, F.A., Hayles, J.A. \& Halverson, G.P., 2018. Linking paleocontinents through triple oxygen isotope anomalies. Geology, 46/2, 179-182. https://doi. org/10.1130/G39470.1

Crockford, P. W., Wing, B.A., Paytan, A., Hodgskiss, M., Mayfield, K.K., Hayles, J.A., Middleton, J.E., Ahm, A-S.C., Johnston, D.T., Caxito, F., Uhlein, G., Halverson, G.P., Eickmann, B., Torres, M. \& Horner, T.J., 2019. Barium-isotopic constraints on the origin of postMarinoan barites. Earth and Planetary Science Letters, 519, 234-244. https://doi.org/10.1016/j.eps1.2019.05.018
Dardenne, M.A., 1978. Síntese sobre a estratigrafia do Grupo Bambuí no Brasil Central. Congresso brasileiro de geologia, Recife. Sociedade Brasileira de Geologia, 2/30, 597-610.

Delpomdor, F. \& Préat, A., 2013. Early and late Neoproterozoic C, O and $\mathrm{Sr}$ isotope chemostratigraphy in the carbonates of West Congo and Mbuji-Mayi supergroups: a preserved marine signature? Palaeogeography Palaeoclimatology Palaeoecology, 389, 35-47. https://doi.org/10.1016/j.palaeo.2013.07.007

Delpomdor, F., Eyles, N., Tack, L. \& Préat, A., 2016. Pre- and postMarinoan carbonate facies of the Democratic Republic of the Congo: glacially- or tectonically-influenced deep-water sediments? Palaeogeography Palaeoclimatology Palaeoecology, 457, 144-157. https://doi.org/10.1016/j.palaeo.2016.06.014

Delpomdor, F., Kant, F., Tack, L. \& Préat, A., 2019. Cyclicity and sequence stratigraphy of the Neoproterozoic uppermost Haut Shiloango-Lukala carbonate ramp system in the Lower Congo region (Democratic Republic of the Congo): Example of tectonostratigraphic control versus climatic changes. Journal of African Earth Sciences, 160, in press. https://doi.org/10.1016/j.jafrearsci.2019.103636

Evans, D.J.A. \& Benn, D.I., 2004. A practical guide to the study of glacial sediments. Arnold Publishers, London, $266 \mathrm{p}$.

Evans, D.A.D., Trindade, R.I.F., Catelani, E.L., D’Agrella-Filho, M.S., Heaman, L.M., Oliveira, E.P., Söderlund, U., Ernst, R.E., Smirnov, A.V. \& Salminen, J.M., 2016. Return to Rodinia? Moderate to high palaeolatitude of the São Francisco/Congo craton at $920 \mathrm{Ma}$. Geological Society, London, Special Publications, 424, 167-190. https://doi.org/10.1144/SP424.1

Folk, R.L., 1954. The distinction between grain size and mineral composition in sedimentary-rock nomenclature. Journal of Geology, 62, 344-359. https://doi.org/10.1086/626171

Font, E., Nédélec, A., Trindade, R.I.F., Macouin, M. \& Charrière, A., 2006. Chemostratigraphy of the Neoproterozoic Mirassol d'Oeste cap dolostones (Mato Grosso, Brazil): An alternative model for Marinoan cap dolostone formation. Earth and Planetary Science Letters, 250, 89-103. https://doi.org/10.1016/j.eps1.2006.06.047

Frimmel, H.E., Tack, L., Basei, M.S., Nutman, A.P. \& Boven, A., 2006. Provenance and chemostratigraphy of the Neoproterozoic West Congolian Group in the Democratic Republic of Congo. Journal of African Earth Sciences, 46, 221-239. https://oi.org/10.1016/j. jafrearsci.2006.04.010

Fullgraf, T., Callec, Y., Thiéblemont, D., Gloaguen, E., Charles, N., Le Métour, J., Prian, J.-P., Boudzoumou, F., Delhaye-Prat, V., Moreau, F., Kebi-Tsoumou, S. \& Ndiele, B., 2015. Notice explicative de la carte géologique de la République du Congo à 1/200 000, Feuille Dolisie. BRGM Editions, Orléans, 307 p.

Guacaneme, C., Babinski, M., Paula-Santos, G.M. \& Perdrosa-Soares, A.C., 2017. C, O, and $\mathrm{Sr}$ isotopic variations in NeoproterozoicCambrian carbonate rocks from Sete Lagoas Formation (Bambuí group), in the Southern Sao Francisco Basin, Brazil. Brazilian Journal of Geology, 47/3, 521-543. https://doi.org/10.1590/23174889201720160126

Halverson, G.P., Hoffman, P.F., Schrag, D.P., Maloof, A.C. \& Rice, A.H.N., 2005. Toward a Neoproterozoic composite carbon-isotope record. GSA Bulletin, 117/9-10, 1181-1207. https://doi.org/10.1130/ B25630.1

Hippertt, J.P., Caxito, F.A., Uhlein, G.J., Nalini, H.A., Sial, A.N., Abreu, A.T. \& Nogueira, L.B., 2019. The fate of a Neoproterozoic intracratonic marine basin: Trace elements, TOC and IRON speciation geochemistry of the Bambuí Basin, Brazil. Precambrian Research, 330, 101-120. https://doi.org/10.1016/j.precamres.2019.05.001

Hoffman, P.F. \& Schrag, D.P., 2002. The snowball Earth hypothesis: testing the limits of global age. Terra Nova, 14/3, 129-155. https:// doi.org/10.1046/j.1365-3121.2002.00408.x

Hoffman, P.F., Halverson, G.P., Domack, E.W., Husson, J.M., Higgins, J.A. \& Schrag, D.P., 2007. Are basal Ediacaran (635 Ma) post-glacial 'cap dolostones' diachronous? Earth and Planetary Science Letters, 258, 114-131. https://doi.org/10.1016/j.eps1.2007.03.032

Iglesias, M. \& Uhlein, A., 2009. Estratigrafia do Grupo Bambuí e coberturas fanerozoicas no vale do rio São Francisco, norte de Minas Gerais. Revista Brasileira de Geociências, 39/2, 256-266. https://doi. org/10.25249/0375-7536.2009392256266 
Jiang, G., Wang, X., Shi, X., Zhang, S., Xiao, S. \& Dong, J., 2010. Organic carbon isotope constraints on the dissolved organic carbon (DOC) reservoir at the Cryogenian-Ediacaran transition. Earth and Planetary Science Letters, 299/1-2, 159-168. https://doi. org/10.1016/j.eps1.2010.08.031

Kuchenbecker, M., 2011. Quimioestratigrafia e proveniência sedimentar da porção basal do Grupo Bambuí em Arcos (MG). Unpublished Master Thesis, Universidade Federal de Minas Gerais, Belo Horizonte, $91 \mathrm{p}$.

Kuchenbecker, M., Babinski, M., Pedrosa-Soares, A.C., Costa, R.D., Lopes-Silva, L. \& Pimenta, F., 2013. Proveniência e análise sedimentar da porção basal do Grupo Bambuí em Arcos (MG). Geologia USP, 13/4, 49-61. https://doi.org/10.5327/Z1519-874X201300040003

Kuchenbecker, M., Babinski, M., Pedrosa-Soares, A.C., Lopes-Silva, L. \& Pimenta, F., 2016. Chemostratigraphy of the lower Bambuí Group, southwestern São Francisco Craton, Brazil: insights on Gondwana paleoenvironments. Brazilian Journal of Geology, 46/1, 145-162. https://doi.org/10.1590/2317-488920160030285

Lachniet, M.S., Larson, G.J., Lawson, D.E., Evenson, E.B. \& Alley, R.B., 2001. Microstructures of sediment flow deposits and subglacial sediments: a comparison. Boreas, 30, 254-264. https://doi. org/10.1111/j.1502-3885.2001.tb01226.x

Li, Z.-X., Evans, D.A.D. \& Halverson, G.P., 2013. Neoproterozoic glaciations in a revised global palaeogeography from the breakup of Rodinia to the assembly of Gondwanaland. Sedimentary Geology, 294, 219-232. https://doi.org/10.1016/j.sedgeo.2013.05.016

Martins, M. \& Lemos, V.B., 2007. Análise estratigráfica das sequências neoproterozóicas da Bacia do São Francisco. Revista Brasileira de Geociências, 37/4, 156-167. https://doi.org/10.25249/03757536.200737S4156167

Martins-Neto, M.A., Pedrosa-Soares, M.A. \& Lima, S.A.A., 2001. Tectono-sedimentary evolution of sedimentary basins from late Paleoproterozoic to late Neoproterozoic in the São Francisco craton and Araçuaí Fold Belt, eastern Brazil. Sedimentary Geology, 141142, 343-370. https://doi.org/10.1016/S0037-0738(01)00082-3

Mickala, O.R., Vidal, L., Boudzoumou, F., Affaton, P., Vandamme, D., Borschneck, D., Mounguengui, M.M., Fournier, F., Malounguila Nganga, D.M. \& Miche, H., 2014. Geochemical characterization of the Marinoan "Cap Carbonate" of the Niari-Nyanga basin (central Africa). Precambrian Research, 255/1, 367-380. https://doi. org/10.1016/j.precamres.2014.10.001

Mickala, O.R., Fournier, F., Affaton, P., Vidal, L., Mounguengui, M.M., Boudzoumou, F., Nganga, D.M.M., Vandamme, D., Miche, N. \& Borschneck, D., 2015. Microfacies, paleoenvironments and development pattern of Neoproterozoic cap carbonates in the NiariNyanga basin (Congo and Gabon republics, central Africa). Journal of African Earth Sciences, 109, 27-36. https://doi.org/10.1016/j. jafrearsci.2015.05.009

Middleton, G.V., 1970. Experimental studies related to problems of flysch sedimentation. In Lajoie, J. (ed.), Flysch Sedimentology in North America. Geological Association of Canada Special Paper, 7, 253-272.

Mutti, E. \& Ricci Lucchi, F., 1978. Turbidites of the northern Apennines: introduction to facies analysis. International Geological Review, 20, 125-166. https://doi.org/10.1080/00206817809471524

Nogueira, A.C.R., Riccomini, C., Sial, A.N., Moura, C.A.V., Trindade, R.I.F. \& Fairchild, T.R., 2007. Carbon and strontium isotope fluctuations and paleoceanographic changes in the late Neoproterozoic Araras carbonate platform, southern Amazon craton, Brazil. Chemical Geology, 237/1-2, 168-190. https://doi. org/10.1016/j.chemgeo.2006.06.016

Okubo, J., Muscente, A.D., Luvizotto, G.L., Uhlein, G.J. \& Warren, L.V., 2018. Phosphogenesis, aragonite fan formation and seafloor environments following the Marinoan glaciation. Precambrian Research, 311, 24-36. https://doi.org/10.1016/j. precamres.2018.04.002

Paula-Santos, G.M., Babinski, M., Kuchenbecker, M., Caetano-Filho, S., Trindade, R.I. \& Pedrosa-Soares, A.C., 2015. New evidence of an Ediacaran age for the Bambuí Group in southern São Francisco craton (eastern Brazil) from zircon $\mathrm{U}-\mathrm{Pb}$ data and isotope chemostratigraphy. Gondwana Research, 28/2, 702-720. https://doi. org/10.1016/j.gr.2014.07.012
Paula-Santos, G.M., Caetano-Filho, S., Babinski, M., Trindade, R.I.F. \& Guacaneme, C., 2017. Tracking connection and restriction of West Gondwana São Francisco Basin through isotope chemostratigraphy. Gondwana Research, 42, 280-305. https://doi.org/10.1016/j. gr.2016.10.012

Paula-Santos, G.M., Caetano-Filho, S., Babinski, B. \& Enzweiler, J., 2018. Rare earth elements of carbonate rocks from the Bambuí Group, southern São Francisco Basin, Brazil, and their significance as paleoenvironmental proxies. Precambrian Research, 305, 327340. https://doi.org/10.1016/j.precamres.2017.12.023

Pedrosa-Soares, A.C. \& Alkmim, F., 2011. How many rifting events preceded the development of the Araçuaí-West Congo Orogen? Geonomos, 19/2, 244-251.

Pedrosa-Soares, A.C., Noce, C.M., Wiedemann, C.M. \& Pinto, C.P., 2001. The Araçuaí-West-Congo Orogen in Brazil: an overview of a confined orogen formed during Gondwanaland assembly. Precambrian Research, 110, 307-323. https://doi.org/10.1016/ S0301-9268(01)00174-7

Pedrosa-Soares, A.C., Alkmim, F.F., Tack, L., Noce, C.M., Babinski, M., Silva, L.C. \& Martins-Neto, M., 2008. Similarities and differences between the Brazilian and African counterparts of the Neoproterozoic Araçuaí-West Congo Orogen. In Pankhurst, J.R., Trouw, R.A.J., Brito Neves, B.B. \& De Wit, M.J. (eds), West Gondwana: Pre-Cenozoic Correlations across the South Atlantic Region. Geological Society, London, Special Publications, 294, 153-172. https://doi.org/10.1144/ SP294.9

Perrella Jr., P., Uhlein, A., Uhlein, G.J., Sial, A.N., Pedrosa-Soares, A.C. \& Lima, O.N.B., 2017. Facies analysis, sequence stratigraphy and chemostratigraphy of the Sete Lagoas Formation (Bambui Group), northern Minas Gerais State, Brazil: evidence of a cap carbonate deposited on the Januária basement high. Brazilian Journal of Geology, 47/1, 59-77. https://doi.org/10.1590/2317-4889201720160112

Préat, A., Prian, J.P., Thiéblemont, D., Mabicka Obame, R. \& Delpomdor, F., 2011. Stable isotopes of oxygen and carbon compositions in the Neoproterozoic of South Gabon (Schisto-Calcaire Subgroup, Nyanga Basin): are cap carbonates and lithoherms recording a particular destabilization event after the Marinoan glaciation? Journal of African Earth Sciences, 60/4, 273-287. https://doi.org/10.1016/j. jafrearsci.2011.03.005

Prian, J.P., Thiéblemont, D., Préat, A., Goujou, J.C., Simo Ndounze, S. \& Ekogha, H., 2009. Notice explicative de la Carte géologique de la République du Gabon à 1/200 000, feuille Ndendé. Editions DGMG - Ministère des Mines, du Pétrole, des Hydrocarbures, Libreville, $384 \mathrm{p}$.

Reis, H.L.S., 2011. Estratigrafia e tectônica da Bacia do São Francisco na zona de emanações de gás natural do baixo Rio Indaiá (MG). Unpublished Master Thesis, Universidade Federal de Ouro Preto, Ouro Preto, $127 \mathrm{p}$.

Reis, H.L.S. \& Alkmim, F.F., 2015. Anatomy of a basin-controlled foreland fold-thrust belt curve: the Três Marias salient, São Francisco basin, Brazil. Marine and Petroleum Geology, 66/4, 711-731. https:// doi.org/10.1016/j.marpetgeo.2015.07.013

Reis, H.L.S. \& Suss, J.F., 2016. Mixed carbonate-siliciclastic sedimentation in forebulge grabens: An example from the Ediacaran Bambuí Group, São Francisco Basin, Brazil. Sedimentary Geology, 339, 83-103. https://doi.org/10.1016/j.sedgeo.2016.04.004

Reis, H.L.S., Suss, J.F., Fonseca, R.C.S. \& Alkmim, F.F., 2016. Ediacaran forebulge grabens of the southern São Francisco basin, SE Brazil: Craton interior dynamics during West Gondwana assembly. Precambrian Research, 302, 150-170. https://doi.org/10.1016/j. precamres.2017.09.023

Ribeiro, J.H., Tuller, M.P. \& Danderfer Filho, A., 1991. Mapeamento geológico da região de Sete Lagoas, Pedro Leopoldo, Matozinhos, Lagoa Santa, Vespasiano, Capim Branco, Prudente de Morais, Confins e Funilândia, Minas Gerais (escala 1:50.000) - Texto Explicativo. Projeto Vida. Belo Horizonte, CPRM, 54 p.

Ribeiro, J.H., Tuller, M.P., Pinho, J.M.M. \& Signorelli, N. 2008. A fácies diamictito da Formação Carrancas, Grupo Bambuí, na região sudoeste da bacia do São Francisco, Minas Gerais. Congresso Brasileiro de Geologia, 44, p. 913. 
Rocha-Campos, A.C., de Brito-Neves, B.B., Babinski, M., dos Santos, P.R., de Oliveira, S.M.B. \& Romano, A.W., 2011. Moema laminites: a newly recognized Neoproterozoic (?) glaciogenic unit, São Francisco Basin, Brazil. In Arnaud, E., Halverson, G.P. \& Shields-Zhou, G. (eds), The Geological Record of Neoproterozoic Glaciations. Geological Society, London, Memoirs, 36, 535-540. https://doi. org/10.1144/M36.50

Rodrigues, J. B., 2008. Proveniência de sedimentos dos grupos Canastra, Ibiá, Vazante e Bambuí - um estudo de zircões detríticos e idades modelo Sm-Nd. Unpublished Ph.D. Thesis, Universidade de Brasília, Brasília, 128 p.

Romano, A.W., 2007. Geologia da Folha Pará de Minas (SE.23-Z-CIV), escala 1:100.000: nota explicativa. UFMG/CPRM-Serviço Geológico do Brasil, Belo Horizonte, 65 p.

Romano, A.W. \& Knauer, L.G., 2003. Evidências da glaciação neoproterozoica na base do Grupo Bambuí - região de Onça do Pitangui - Minas Gerais. Simpósio de Gelogia de Minas Gerais, 12, p. 1.

Romero, J.A.S., Lafon, J.M., Nogueira, A.C.R. \& Soares, J.L., 2013. Sr isotope geochemistryand $\mathrm{Pb}-\mathrm{Pb}$ geochronology of the Neoproterozoic cap carbonates, Tangara da Serra, Brazil. International Geology Review, 55, 185-203. https://doi.org/10.1080/00206814.2012.6925 17

Rudnitzki, I.D., Romero, G.R., Hidalgo, R. \& Nogueira, A.C.R., 2016. High frequency peritidal cycles of the upper Araras Group: Implications for disappearance of the Neoproterozoic carbonate platform in southern Amazon Craton. Journal of South American Earth Sciences, 65, 67-78. https://doi.org/10.1016/j.jsames.2015.11.006

Sansjofre, P., Trindade, R.I.F., Ader, M., Soares, J.L., Nogueira, A.C.R. \& Tribovillard, N., 2014. Paleoenvironmental reconstruction of the Ediacaran Araras platform (Western Brazil) from the sedimentary and trace metals record. Precambrian Research, 241, 185-202. https://doi.org/10.1016/j.precamres.2013.11.004

Santos, R.V., Alvarenga, C.J.S., Dardenne, M.A., Sial, A.N. \& Ferreira, V.P., 2000. Carbon and oxygen isotope profiles across MesoNeoproterozoic limestones from central Brazil: Bambuí and Paranoá groups. Precambrian Research, 104, 107-122. https://doi. org/10.1016/S0301-9268(00)00082-6

Sgarbi, G.N.C, Sgarbi, P.B. de A., Campos, J.E.G., Dardenne, M.A. \& Penha, U.C. 2001. Bacia Sanfranciscana: o registro fanerozóico da bacia do São Francisco. In Pinto, C.P. \& Martins-Neto, M.A. (eds), Bacia do São Francisco: Geologia e Recursos Naturais. SBG-MG, Belo Horizonte, 93-138.

Shanmugan, G., 2000. 49 years of the turbidite paradigm (1950s-1990s): deep-water processes and facies models - a critical perspective. Marine and Petroleum Geology, 17, 285-342. https://doi.org/10.1016/ S0264-8172(99)00011-2

Shen, Y., Zhang, T. \& Chu, X., 2005. C-isotopic stratification in a Neoproterozoic postglacial ocean. Precambrian Research, 137, 243251. https://doi.org/10.1016/j.precamres.2005.03.004

Sial, A.N., Dardenne, M.A, Misi, A., Pedreira, A.J., Gaucher, C., Ferreira, V.P. Silva-Filho, M.A., Uhlein, A., Pedrosa-Soares, A.C., Santos, R.V., Egydio-Silva, M., Babinski, M., Alvarenga, C.J.S., Fairchild, T.R. \& Pimentel, M.M., 2009. The São Francisco palaeocontinent. In Gaucher, C., Sial, A.N., Halverson, G.P. \& Frimmel, H.E. (eds), Neoproterozoic-Cambrian Tectonics, Global Change and Evolution: a Focus on Southwestern Gondwana. Amsterdam, Elsevier, Developments in Precambrian Geology, 16 31-69. https://doi. org/10.1016/S0166-2635(09)01603-X

Sikorski, J., 1958. Echelle stratigraphique provisoire des étages C1C2-C3 du Système Schisto-Calcaire du Bas-Congo. CIMINGA, note no. 15 .

Straathof, G.B., 2011. Neoproterozoic low latitude glaciations: an African perspective. Unpublished Ph.D. Thesis, University of Edinburgh, Edinburgh, 283 p.

Thiéblemont, D., Castaing, C., Billa, M., Bouton, P. \& Préat, A., 2009. Notice explicative de la carte géologique et des ressources minérales de la République Gabonaise à 1/1 000 000. Editions DGMG Ministère des Mines, du Pétrole, des Hydrocarbures, Libreville, 384 p.

Trompette, R.R., 1994. Geology of Western Gondwana (2000-500 Ma). Pan-African-Brasiliano aggregation of South America and Africa. Balkema, Rotterdam, 380 p.
Tuller, M.P., Ribeiro, J.H., Signorelli, N., Féboli, W.L. \& Pinho, J.M.M., 2010. Projeto Sete Lagoas-Abaeté: Folha Contagem (1:100.000). Serviço Geológico do Brasil-CPRM, Belo Horizonte.

Uhlein, A., Alvarenga, C.J.S., Trompette, R., Dupont, H.S.J.B., Egydio-Silva, M., Cukrov, N. \& Lima, O.N.B., 2004. Glaciação neoproterozóica sobre o Cráton do São Francisco e faixas dobradas adjacentes. In Mantesso-Neto, V., Bartorelli, A., Carneiro, C.D.R. \& Brito-Neves, B.B. (eds), Geologia do Continente Sul Americano: Evolução da obra de Fernando Flávio Marques de Almeida. Beca, São Paulo, 539-553.

Uhlein, A., Alvarenga, C.J.S., Dardenne, M.A. \& Trompette, R.R., 2011. The glaciogenic Jequitaí Formation, southeastern Brazil. In Arnaud, E., Halverson, G.P. \& Shields-Zhou, G. (eds), The Geological Record of Neoproterozoic Glaciations. Geological Society, London, Memoirs, 36, 51-66. https://doi.org/10.1144/M36.51

Uhlein, G. J., 2014. Proveniência sedimentar e estratigráfica das formações Carrancas e Lagoa Formosa e a evolução do Grupo Bambuí (635-570 Ma) em Minas Gerais. Unpublished Master Thesis, Universidade Federal de Minas Gerais, Belo Horizonte, 147 p.

Uhlein, G.J., Carvalho, J.F.M.G., Uhlein, A., Caxito, F.A., Halverson, G.P. \& Sial, A.N., 2012. Estratigrafia e sedimentologia da Formação Carrancas, Grupo Bambuí, nas regiões de Belo Horizonte e Pitangui - MG. Geonomos, 20/2, 79-97. https://doi.org/10.18285/geonomos. v2i20.250

Uhlein, G.J., Uhlein, A., Halverson, G.P., Stevenson, R., Caxito, F.A., Cox, G.M. \& De Carvalho, J.F.M.G., 2016. The Carrancas Formation, Bambuí Group: A record of pre-Marinoan sedimentation on the southern São Francisco craton, Brazil. Journal of South American Earth Sciences, 71, 1-16. https://doi.org/10.1016/j. jsames.2016.06.009

Uhlein, G.J., Uhlein, A., Stevenson, R., Halverson, G.P., Caxito, F.A. \& Cox, G.M., 2017. Early to late Ediacaran conglomeratic wedges from a complete foreland basin cycle in the southwest São Francisco Craton, Bambuí Group, Brazil. Precambrian Research, 299, 101-116. https://doi.org/10.1016/j.precamres.2017.07.020

Uhlein, G.J., Uhlein, A., Pereira, E., Caxito, F.A., Okubo, J., Warren, L.V. \& Sial, A.N., 2019. Ediacaran paleoenvironmental changes recorded in the mixed carbonate-siliciclastic Bambuí Basin, Brazil. Palaeogeography, Palaeoclimatology, Palaeoecology, 517, 39-51. https://doi.org/10.1016/j.palaeo.2018.12.022

Valeriano, C., Machado. N., Simonetti, A., Valadares, C.S., Seer, H.J. \& Simões, L.S.A., 2004. U-Pb geochronology of the southern Brasília belt (SE-Brazil): sedimentary provenance, Neoproterozoic orogeny and assembly of West Gondwana. Precambrian Research, 130, 2755. https://doi.org/10.1016/j.precamres.2003.10.014

Vieira, L.C., Almeida, R.P., Trindade, R.I.F., Nogueira, A.C.R. \& Janikian, L., 2007.AFormação Sete Lagoas em sua área tipo: fácies, estratigrafia e sistemas deposicionais. Revista Brasileira de Geociências, 37/4, 1-14. https://doi.org/10.25249/0375-7536.200737S4114

Vieira, L.C., Nédélec, A., Fabre, S., Trindade, R.I.F.\& Almeida, R.P., 2015. Aragonite crystal fans in Neoproterozoic cap carbonates: a case study from Brazil and implications for the post-snowball earth coastal environment. Journal of Sedimentary Research, 85, 285-300. https://doi.org/10.2110/jsr.2015.21

Warren, L.V., Quaglio, F., Riccomini, C., Simoes, M.G., Poiré, D.G., Strikis, N.M., Anelli, A. \& Strikis, P.C., 2014. The puzzle assembled: Ediacaran guide fossil Cloudina reveals an old proto-Gondwana seaway. Geology, 42/5, 391-394. https://doi.org/10.1130/G35304.1

Manuscript received 31.10.2018, accepted in revised form 22.11.2019, available online 04.01.2020. 


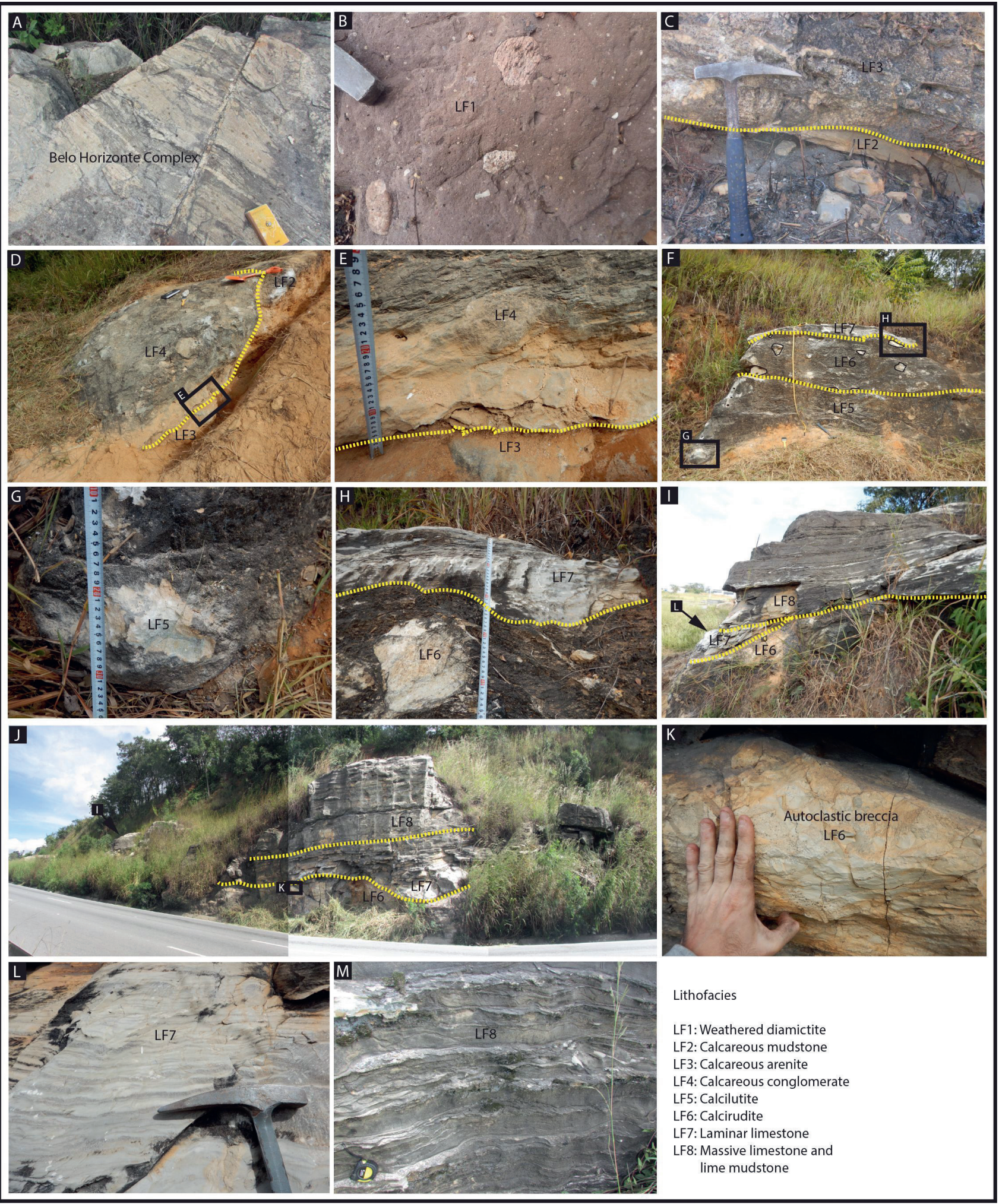

Plate 1. Lithofacies LF1 to LF8 of the Carrancas Formation and the Pedro Leopoldo Member at the São José da Lapa outcrop section. (A) Orthogneiss of the Archean Belo Horizonte Complex located few metres above the São José da Lapa outcrop section. (B) Weathered diamictite (LF1) with granitic clasts of the Carrancas Formation. (C) Undulating contact between calcareous mudstone (LF2) and calcareous arenite (LF3). (D) Up than $40 \mathrm{~cm}$-thick lenticular conglomeratic interbed (LF4) within the calcareous arenite (LF3). Notice the presence of sand-to pebble-sized clasts of limestone, sandstone, quartz, granite and gneiss. Orientation directions are discussed in text. (E) Contact between LF3 and LF4 marked by shear zone texture. (F) Photograph of contacts between the calcilutite (LF5) and calcirudite (LF6), and conformable contact, marked by an erosional surface, between the calcirudite (LF6) and the laminated limestone (LF7). (G) Blue-grey massive crystalline calcilutite (LF5). (H) Photograph of the conformable contact between LF6 and LF7. LF6 consists of granule- to pebble-sized clasts of limestone partially supported by calcareous microstylolitic seams of muddy to silty matrix. (I) Photograph of the SLJ6 outcrop in a N-S profile. (J) Lenticular bed of LF7, and erosive surface at the base with LF6. Sharp to slightly undulating contact between the laminar limestone (LF7) and lime mudstone-massive limestones (LF8). (K) Autoclastic brecciated level of the LF6 surrounded by silty to sandy matrix close contact with the massive limestone (LF7). (L) Centimetre-thick successions of irregular alternations of light grey crystalline limestone and darker crystalline limestone with aragonite pseudomorph crystal fans arranged in growth position (LF7). (M) Centimetre- to decimetrethick successions of alternations of coarse-grained crystalline lime mudstone and massive limestone (LF8). 